\title{
Cretaceous and Tertiary Paleogeographic Reconstructions for the Uinta-Piceance Basin Study Area, Colorado and Utah
}

\section{U.S. GEOLOGICAL SURVEY BULLETIN 1787-Q}

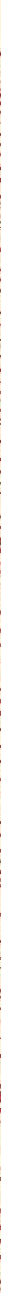




\section{AVAILABILITY OF BOOKS AND MAPS OF THE U.S. GEOLOGICAL SURVEY}

Instructions on ordering publications of the U.S. Geological Survey, along with the last offerings, are given in the current-year issues of the monthly catalog "New Publications of the U.S. Geological Survey." Prices of available U.S. Geological Survey publications released prior to the current year are listed in the most recent annual "Price and Availability List." Publications that are listed in various U.S. Geological Survey catalogs (see back inside cover) but not listed in the most recent annual "Price and Availability List" are no longer available.

Prices of reports released to the open files are given in the listing "U.S. Geological Survey Open-File Reports," updated monthly, which is for sale in microfiche from the U.S. Geological Survey Books and Open-File Reports Sales, Box 25286, Denver, CO 80225.

Order U.S. Geological Survey publications by mail or over the counter from the offices given below.

\section{BY MAIL}

\section{Books}

Professional Papers, Bulletins, Water-Supply Papers, Techniques of Water-Resources Investigations, Circulars, publications of general interest (such as leaflets, pamphlets, booklets), single copies of periodicals (Earthquakes \& Volcanoes, Preliminary Determination of Epicenters), and some miscellaneous reports, including some of the foregoing series that have gone out of print at the Superintendent of Documents, are obtainable by mail from

\section{U.S. Geological Survey, Books and Open-File Report Sales} Box 25286

Denver, CO 80225

Subscriptions to periodicals (Earthquakes \& Volcanoes and Preliminary Determination of Epicenters) can be obtained ONLY from

\section{Superintendent of Documents \\ U.S. Government Printing Office \\ Washington, DC 20402}

(Check or money order must be payable to Superintendent of Documents.)

\section{Maps}

For maps, address mail order to

$$
\begin{aligned}
& \text { U.S. Geological Survey, Map Sales } \\
& \text { Box } 25286 \\
& \text { Denver, CO } 80225
\end{aligned}
$$

Residents of Alaska may order maps from

$$
\begin{aligned}
& \text { U.S. Geological Survey, Map Sales } \\
& 101 \text { Twelfth Ave., Box } 12 \\
& \text { Fairbanks, AK } 99701
\end{aligned}
$$

\section{OVER THE COUNTER}

\section{Books}

Books of the U.S. Geological Survey are available over the counter at the following U.S. Geological Survey offices, all of which are authorized agents of the Superintendent of Documents.

- ANCHORAGE, Alaska-4230 University Dr., Rm. 101

- ANCHORAGE, Alaska-605 West 4th Ave., Rm G-84

- DENVER, Colorado-Federal Bldg., Rm. 169, 1961 Stout St.

- LAKEWOOD, Colorado-Federal Center, BIdg. 810

- MENLO PARK, California-BIdg. 3, Rm. 3128, 345 Middlefield Rd.

- RESTON, Virginia-National Center, Rm. 1C402, 12201 Sunrise Valley Dr.

- SALT LAKE CITY, Utah-Federal Bldg., Rm. 8105, 125 South State St.

- SAN FRANCISCO, California-Customhouse, Rm. 504, 555 Battery St.

- SPOKANE, Washington-U.S. Courthouse, Rm. 678, West 920 Riverside Ave.

- WASHINGTON, D.C.-U.S. Department of the Interior Bldg., Rm. 2650, 1849 C St., NW.

\section{Maps}

Maps may be purchased over the counter at the U.S. Geological Survey offices where books are sold (all addresses in above list) and at the following Geological Survey offices:

- ROLLA, Missouri-1400 Independence Rd.

- FAIRBANKS, Alaska-New Federal Building, 101 Twelfth Ave. 
Chapter Q

\section{Cretaceous and Tertiary Paleogeographic Reconstructions for the Uinta-Piceance Basin Study Area, Colorado and Utah}

\section{By K.J. FRANCZYK, T.D. FOUCH, R.C. JOHNSON, C.M. MOLENAAR, and W.A. COBBAN}

A multidisciplinary approach to research studies of sedimentary rocks and their constituents and the evolution of sedimentary basins, both ancient and modern 


\title{
U.S. DEPARTMENT OF THE INTERIOR MANUEL LUJAN, JR., Secretary
}

\author{
U.S. GEOLOGICAL SURVEY
}

Dallas L. Peck, Director

Any use of trade, product, or firm names in this publication is for descriptive purposes only and does not imply endorsement by the U.S. Government

UNITED STATES GOVERNMENT PRINTING OFFICE: 1992

For sale by the

Book and Open-File Report Sales

U.S. Geological Survey

Federal Center

Box 25425

Denver, CO 80225

\section{Library of Congress Cataloging-in-Publication Data}

Cretaceous and Tertiary paleogeographic reconstructions for the Uinta-Piceance basin study area, Colorado and Utah / by K.J. Franczyk ... [et al.].

p. cm. - (Evolution of sedimentary basins-Uinta and Piceance Basins ; ch. Q) (U.S. Geological Survey bulletin ; 1787-Q)

"A multidisciplinary approach to research studies of sedimentary rocks and their constituents and the evolution of sedimentary basins, both ancient and modern."

Includes bibliographical references.

Supt. of Docs. no.: I 19.3:1787-Q

1. Paleogeography-Uinta Basin (Utah and Colo.). 2. PaleogeographyColorado-Piceance Creek Basin. 3. Geology, Stratigraphic-Cretaceous. 4. Geology, Stratigraphic-Tertiary. 5. Geology, Structural-Uinta Basin (Utah and Colo.). 6. Geology, Structural-Colorado-Piceance Creek Basin. 7. Uinta Basin (Utah and Colo.). 8. Piceance Creek Basin (Colo.).

I. Franczyk, Karen J. II. Series. III. Series: U.S. Geological Survey bulletin ; 1787-Q.

QE75.B9

[QE501.4.P3]

$557.3 \mathrm{~s}-\mathrm{dc} 20$ 


\title{
CONTENTS
}

\author{
Abstract Q1 \\ Introduction Q1 \\ Acknowledgments Q4 \\ Methods Q4 \\ Paleogeographic reconstructions Q4 \\ Early Cenomanian Neogastroplites americanus faunal zone Q4 \\ Early Turonian Vascoceras birchbyi faunal zone $\quad \mathbf{Q 8}$ \\ Late middle Turonian Prionocyclus hyatti faunal zone Q9 \\ Middle Coniacian Inoceramus deformis faunal zone $\quad$ Q11 \\ Late Santonian Desmoscaphites bassleri faunal zone $\quad$ Q12 \\ Early Campanian Scaphites hippocrepis I faunal zone Q13 \\ Late early Campanian Baculites mclearni faunal zone Q14 \\ Early late Campanian Baculites asperiformis faunal zone Q15 \\ Middle late Campanian Baculites perplexus faunal zone $\quad$ Q17 \\ Late late Campanian Exiteloceras jenneyi faunal zone $\quad$ Q18 \\ Early Maastrichtian Baculites reesidei faunal zone Q19 \\ Middle Maastrichtian Baculites clinolobatus faunal zone $\quad$ Q21 \\ Late Maastrichtian Q22 \\ Middle Paleocene Q23 \\ Early late Paleocene Q23 \\ Early Eocene Q26 \\ Middle Eocene Q28 \\ Late Eocene Q29 \\ Latest Eocene and (or) earliest Oligocene $\quad$ Q29 \\ Summary Q31 \\ References cited Q33
}

\section{FIGURES}

1. Location map of the Uinta-Piceance basin study area Q2

2. Stratigraphic cross section of Cretaceous rocks from central Utah to northeastern Colorado Q3

3. Chart showing molluscan fossil zones for the Upper Cretaceous, Western Interior of the United States Q5

4. Generalized geologic map of the study area, showing distribution of Cretaceous and Tertiary sedimentary rocks and Tertiary igneous rock Q6

5-24. Paleogeographic reconstruction maps showing time of:

5 Early Cenomanian Neogastroplites americanus faunal zone Q8

6. Early Turonian Vascoceras birchbyi faunal zone Q9

7. Late middle Turonian Prionocyclus hyatti faunal zone Q10

8. Middle Coniacian Inoceramus deformis faunal zone Q11

9. Late Santonian Desmoscaphites bassleri faunal zone Q12

10. Early Campanian Scaphites hippocrepis I faunal zone Q14

11. Late early Campanian Baculites mclearni faunal zone Q15

12. Early late Campanian Baculites asperiformis faunal zone Q16

13. Middle late Campanian Baculites perplexus faunal zone $\mathbf{Q 1 7}$ 
14. Late late Campanian Exiteloceras jenneyi faunal zone Q18

15. Early Maastrichtian Baculites reesidei faunal zone Q20

16. Middle Maastrichtian Baculites clinolobatus faunal zone Q21

17. Late Maastrichtian $\mathbf{Q 2 2}$

18. Middle Paleocene Q24

19. Early late Paleocene Q25

20. Early Eocene Q26

21. Middle Eocene (time 1) Q28

22. Middle Eocene (time 2), representing Lake Uinta's phase of maximum expansion that included the Mahogany oil-shale bed deposition Q30

23. Late Eocene Q31

24. Latest Eocene and (or) early Oligocene Q32

25. Chart showing structural and depositional events in the study area from late Early Cretaceous to late Oligocene time Q33

TABLE

1. Lithologies corresponding to depositional environments in each of the three major depositional settings within the study area

Q7

CONVERSION FACTORS FOR SOME SI METRIC AND U.S. UNITS OF MEASURE

\begin{tabular}{|c|c|c|}
\hline To convert from & To & Multiply by \\
\hline Feet $(\mathrm{ft})$ & Meters (m) & 0.3048 \\
\hline Miles (mi) & Kilometers (km) & 1.609 \\
\hline Pounds (lb) & Kilograms (kg) & 0.4536 \\
\hline Degrees Fahrenheit $\left({ }^{\circ} \mathrm{F}\right)$ & Degrees Celsius $\left({ }^{\circ} \mathrm{C}\right)$ & Temp ${ }^{\circ} \mathrm{C}=\left(\right.$ temp $\left.{ }^{\circ} \mathrm{F}-32\right) / 1.8$ \\
\hline
\end{tabular}




\title{
Cretaceous and Tertiary Paleogeographic Reconstructions for the Uinta-Piceance Basin Study Area, Colorado and Utah
}

\author{
By K.J. Franczyk, T.D. Fouch, R.C. Johnson, C.M. Molenaar, and W.A. Cobban
}

\begin{abstract}
Paleogeographic reconstructions for early Late Cretaceous through early Oligocene time in the Uinta-Piceance basin study area illustrate the major changes that accompanied incursion of the Cretaceous sea, tectonism in the Sevier thrust belt, eustatic changes, break-up of the foreland, intermontane basin formation, and establishment and demise of large lacustrine complexes. Throughout most of the Late Cretaceous, the study area was part of the foreland basin in which depositional patterns were controlled primarily by both tectonism in the Sevier thrust belt and eustatic changes. In late Campanian time, the gradual withdrawal of the Cretaceous sea from the western part of the study area coincided with a decrease in subsidence rates in areas closest to the thrust belt. Both events resulted in broader nonmarine depositional areas than had existed previously for much of the Late Cretaceous. Subsequently in the west-central and southwestern part of the study area, late-stage, thin-skinned thrusting in the Sevier belt resulted in the formation of small intermontane basins (piggyback basins) on top of the thrust allochthon in what had previously been part of the foreland. Shortly thereafter, in latest Campanian or earliest Maastrichtian time, basement-involved uplift of the San Rafael structure created both a new intermontane basin between it and the thrust belt and a broad, nonsubsiding region in the south-central part of the study area. Concurrently, thin-skinned thrusting continued in the northwestern part of the study area.
\end{abstract}

By late Maastrichtian time, the sea had completely withdrawn from the study area, movement on the Uinta and Sawatch uplifts was initiated, and deposition was restricted to a few small intermontane basins in the western part of the study area. Basement-involved uplifts continued to develop and depositional areas remained restricted into the middle Paleocene. The intermontane basins that characterized much

Manuscript approved for publication July 30, 1990. of the Paleogene formed by middle Paleocene time, and deposition occurred primarily in alluvial, wetland, and shallow lacustrine environments. Although the wetland and shallow lacustrine depositional areas expanded greatly in late Paleocene time, it was not until the early Eocene that regionally extensive lakes formed in both the Uinta and Piceance basins. These two lakes expanded and formed a single large lake in middle Eocene time. Shortly thereafter, clastic influx from the north, which included abundant reworked volcanic sediments, began to fill in the Piceance basin and displace the lake westward. The lake continued to shrink and retreat westward during the late Eocene and finally disappeared in latest Eocene or earliest Oligocene time. The presence of tuff beds in these youngest lacustrine deposits indicates continued volcanism, probably from sources both outside of and in the westernmost part of the study area. The Uinta basin was filled with clastics shed during the final tectonic event in the Uinta uplift; concurrently, volcanic deposits and reworked volcanic detritus accumulated in the western part of the study area.

\section{INTRODUCTION}

This report presents our synthesis of the geologic history during the Late Cretaceous and Paleogene in an area including and surrounding the Uinta and Piceance basins. This study was conducted as part of the U.S. Geological Survey's Evolution of Sedimentary Basins Program, whose objective is an interpretation of the Phanerozoic history of selected energy-resource-rich basins. Because the extent of Tertiary deposits is generally used to define the present Uinta and Piceance basins, the basin study area boundaries encompass a much larger area in order to reconstruct the regional history prior to the Tertiary. Our map area (fig. 1) corresponds to the base map for the Uinta and Piceance basin study area, which enables us to illustrate regional variations in depositional environments and tectonic 


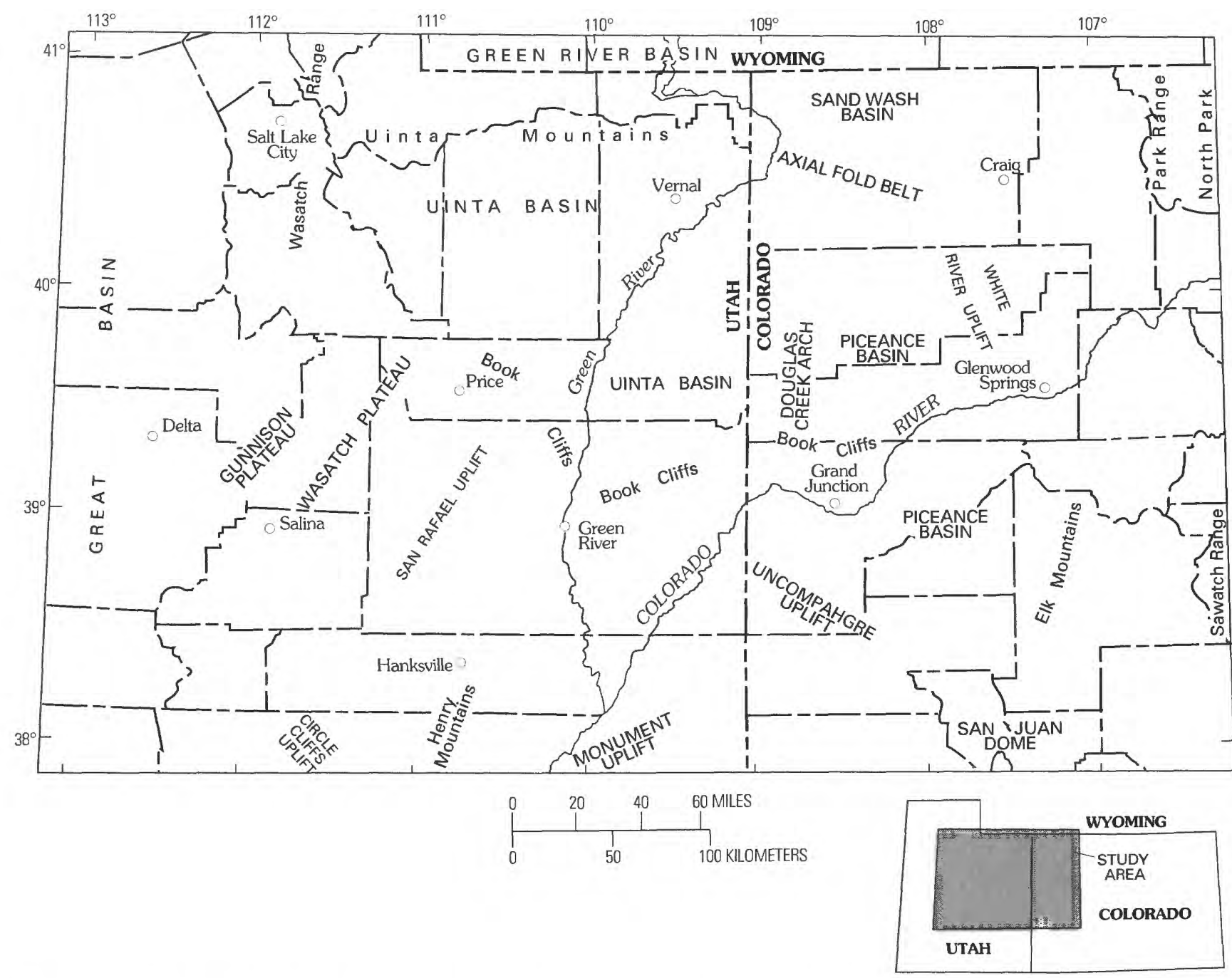

Figure 1. Location map of the Uinta-Piceance basin study area, Utah, Colorado, and Wyoming.

activity. Detailed discussions of the depositional history, particularly for the Tertiary, in the northernmost part of the map area are beyond the scope of this report.

To portray the evolution of the Cretaceous and Tertiary terrane, we reconstructed the paleogeography of the study area for 17 time intervals, 12 of which are based on well-established marine faunal zones. The reconstructions cover early Late Cretaceous through early Oligocene time. Because Lower Cretaceous strata in the study area are poorly constrained with respect to age and extent and because post-early Oligocene age deposits are restricted, these sequences were excluded from our study. Figure 2, a west-to-east stratigraphic cross section of Cretaceous rocks within and east of the study area, shows the thicknesses and regional relations of many of the units that are on the paleogeography maps.

Our reconstructions represent both a synthesis of the literature and the incorporation of recent paleontologic and sedimentologic data as well as new tectonic interpretations and stratigraphic correlations. Reconstructions for earliest
Late Cretaceous, latest Cretaceous, and earliest Tertiary time contain major revisions from previous work. It is beyond the scope of this report to cite the large volume of literature that exists on the Cretaceous and Tertiary strata in the study area. The references cited herein represent our principal sources for ideas and information used in this study.

Changes in the paleogeography through the Late Cretaceous and early Tertiary were accompanied by paleoclimatic changes. Except for parts of the Eocene (MacGinitie, 1969), detailed paleoclimatic reconstructions for this study area are lacking. Regional paleoclimatic reconstructions for the Late Cretaceous and early Tertiary in low to middle latitudes in the Westem Interior (Wolfe and Upchurch, 1987) indicate that the Late Cretaceous was characterized by a warm, subhumid climate. Temperatures declined slightly in the Campanian and early Maastrichtian and increased again in the latest Maastrichtian. A change to a wetter climate marked the onset of the Tertiary. A warm, humid climate persisted into the early Eocene, and the early 


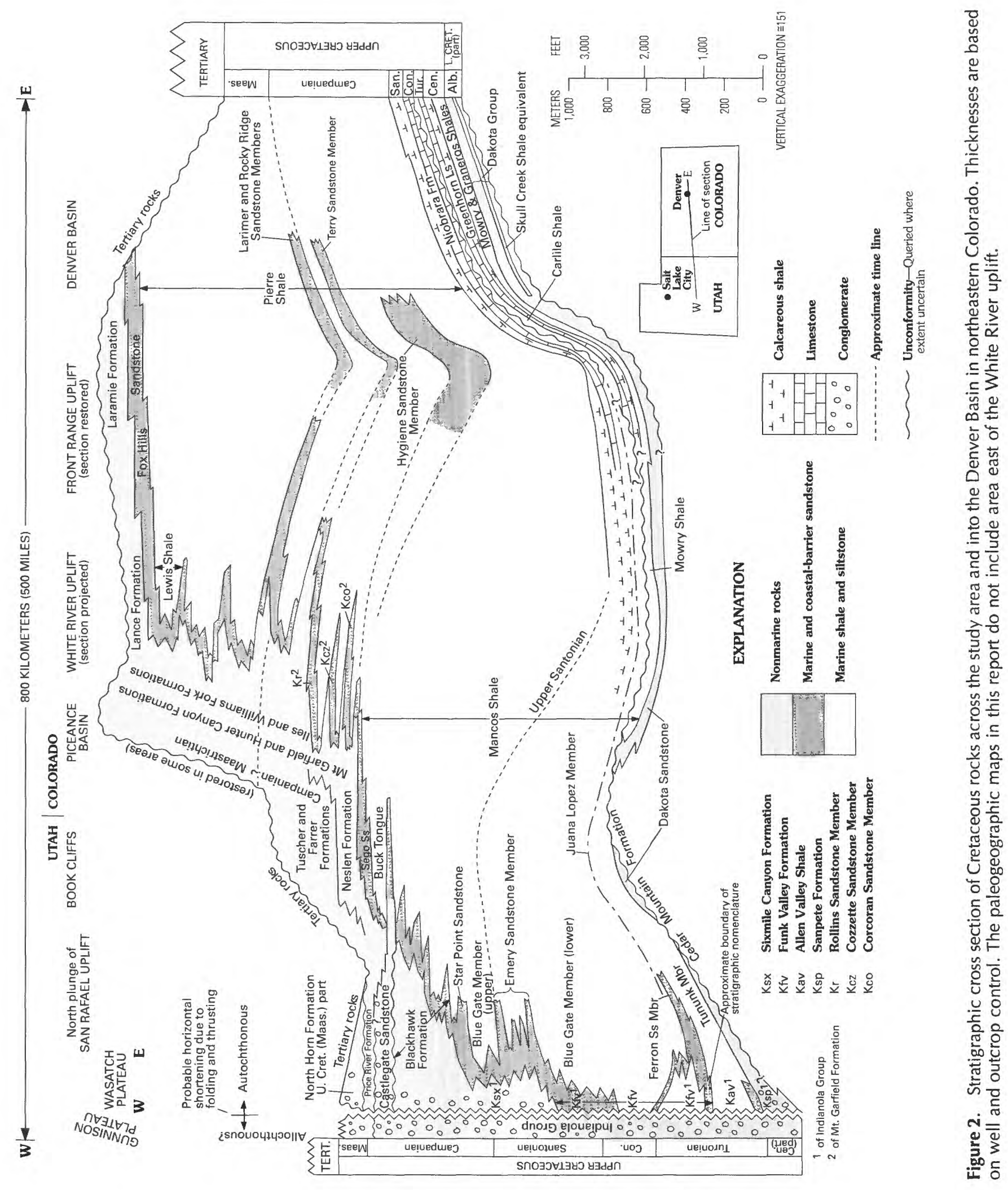


Eocene was probably warmer than the Late Cretaceous (Wolfe and Upchurch, 1987). An overall cooling and drying trend with minor climatic fluctuations marked the remainder of the Eocene (G.R. Upchurch, oral commun., 1990).

\section{ACKNOWLEDGMENTS}

This work was conducted under the U.S. Geological Survey Evolution of Sedimentary Basins Program in conjunction with the Utah Geological and Mineralogical Survey. We greatly appreciated and relied on the discussions and reviews by numerous people who have worked in this area, particularly Bruce Bryant, William B. Cashion, William A. Cobban, John R. Dyni, Richard M. Forester, Timothy F. Lawton, E. Allen Merewether, Douglas J. Nichols, and Fred Peterson.

\section{METHODS}

Most of the Cretaceous time intervals used in the reconstructions correspond to a reference faunal zone for the Western Interior (fig. 3). These intervals are not equally. spaced throughout the Late Cretaceous. Rather, these particular intervals are used because either they correspond to most of the transgressive and regressive maxima within the study area or they correspond to times of significant paleogeographic changes resulting from tectonism. During latest Cretaceous and early Tertiary time, nonmarine rocks predominate; these are dated by using palynomorph, ostracode, charophyte, and mollusk assemblages. The age resolution obtained from using these paleontologic materials is not as great as that provided by marine mollusks, so much broader intervals (such as late Paleocene) are used. Middle Eocene through Oligocene rocks contain tuffaceous beds that are radiometrically dated.

The base map area, which includes parts of northwestern Colorado, northeastern Utah, and the southernmost edge of Wyoming, encompasses about 222,000 km² (square kilometers). Figure 4 is a generalized geologic map showing the distribution of Cretaceous and Tertiary outcrops in this area. The geologic map can be compared to the paleogeographic maps to identify areas where the reconstructions have been made by interpolating between outcrops. Because drill holes have not penetrated the Cretaceous section in a large part of the Uinta basin, the paleogeographic interpretations are speculative, but they are consistent with regional relations. Locally, and particularly in the southern and western parts of the map area, the limits of Tertiary deposition are unknown because of extensive erosion.

The exact locations, extent, and relief of the highlands are difficult to determine because their positions are approximated from inferred associations with wedges of coarse detritus that we believe were derived from them. The age, extent, and stratigraphic identity of these poorly exposed conglomeratic nonmarine units, in turn, are generally poorly constrained.

Because detailed paleogeographic reconstructions are only locally possible, the paleogeographic subdivisions are generalized. These subdivisions are highlands, alluvial fan, alluvial plain, coastal plain, open marine, lacustrine, marginal lacustrine, and wetlands. Lithofacies provide the basis for determining the paleogeographic subdivisions. In order to relate the paleogeography to the rock record, table 1 lists the lithologies that correspond to particular depositional environments within the three depositional settings that occurred in the study area during the Late Cretaceous and the Paleogene. Patterns are used on the map figures to delineate the subdivisions, and except for the position of the marine shoreline, the boundaries are gradational. Some areas, especially those within intermontane basins, may be characterized by a mixture of depositional environments; these are portrayed schematically on the maps.

In some reconstructions, highlands patterns are differentiated to indicate (1) high to moderate relief, (2) moderate to low relief, and (3) low relief. These terms are relative; quantitative limits are not suggested. Based on the grain size and distribution of detritus shed from these uplifts, the relief of the uplifts varied greatly. During latest Cretaceous and early Tertiary time, large areas apparently either were not subsiding or were slightly positive but supplying little or no sediment. These areas are difficult to distinguish from areas of low relief; therefore, on the paleogeography maps, the symbol for low-relief highlands is also used for these nonsubsiding areas. The area west of a line extending from approximately the southwest corner of Wyoming through Salina, Utah, is presently allochthonous terrain, that is, most pre-Paleocene rocks have been transported east as thrust sheets. For Cretaceous reconstructions in this area, the paleogeography is restored 5 to 65 kilometers to the west to allow for thrust displacement.

Stratigraphic nomenclature is not a primary focus in these reconstructions. For reference, the units that formed in the various depositional environments are listed with that environment on the paleogeography maps. Units that are of several ages generally appear on more than one paleogeographic map. Stratigraphic nomenclature is also used in the text to help elucidate problems-such as in correlation, age, and depositional origin - that create uncertainties in the reconstructions.

\section{PALEOGEOGRAPHIC RECONSTRUCTIONS}

\section{Early Cenomanian Neogastroplites americanus Faunal Zone}

The first incursion of the shallow, epicontinental Cretaceous sea into the map area occurred during the early 

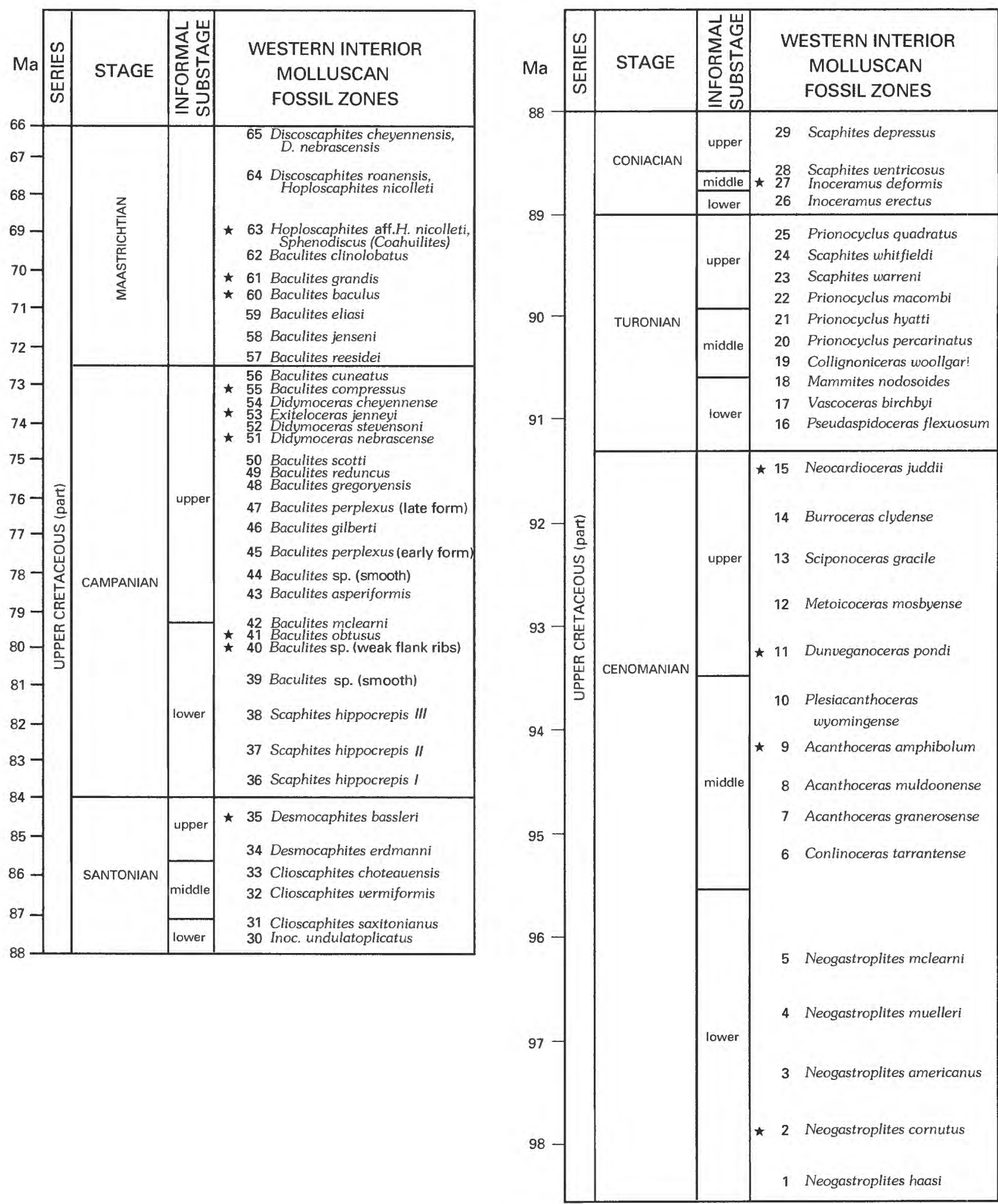

Figure 3. Molluscan fossil zones for the Upper Cretaceous, Western Interior of the United States, modified (W.A. Cobban, written commun., 1989) from Molenaar and Cobban (1991) and Fouch and others (1983). Stars indicate sequential location of rocks radiometrically dated by Obradovich and Cobban (1975) and by J.D. Obradovich (oral commun., 1989). 

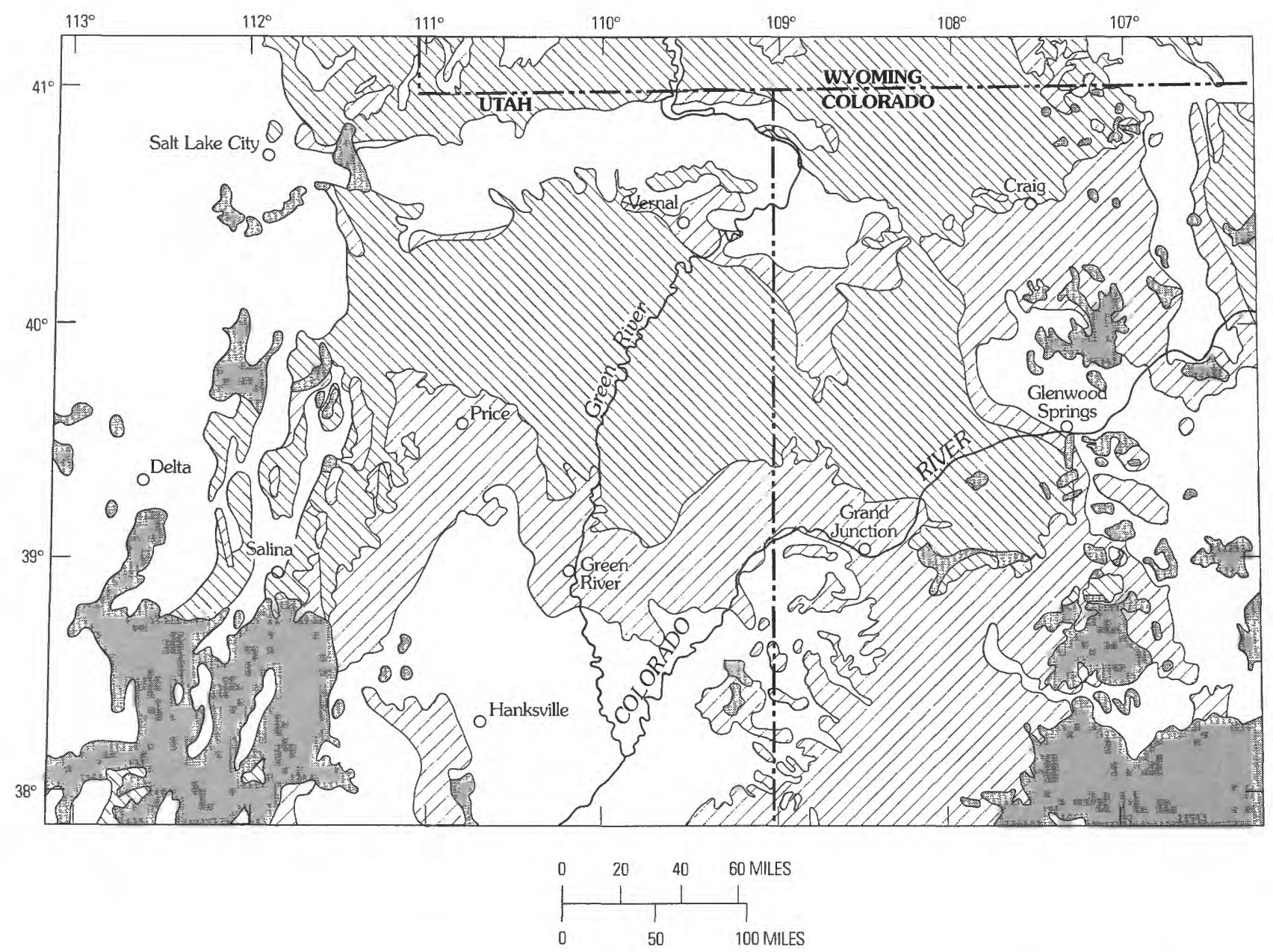

EXPLANATION

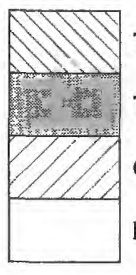

Tertiary rock

Tertiary volcanic and intrusive rock

Cretaceous rock

Pre-Cretaceous and post-Tertiary rock-

Dominantly pre-Cretaceous rock; Quaternary

deposits abundant in western map area

Figure 4. Generalized geology of the study area, showing distribution of Cretaceous and Tertiary sedimentary rocks and Tertiary igneous rock. (Modified from Oetking and others, 1967, and Renfro and Feray, 1972.) Distribution of outcrop areas indicates extent of surface control. Subsurface control of Cretaceous rocks is limited throughout much of the Uinta basin where these rocks are deeply buried.

Cenomanian. Figure 5 shows the paleogeography at the maximum point of the sea's transgression when a dominantly northwesterly trending shoreline was established across the central part of this area. The offshore marine deposits of the Mowry Shale grade southwestward into the nearshore marine deposits of the Dakota Sandstone, which in turn grades into mud-dominated, nonmarine deposits of the Cedar Mountain Formation. A coastal-plain environment was probably present landward of the Mowry shoreline, but it is non-coal bearing and difficult to separate from the mud-rich alluvial-plain environment. The Cedar Mountain grades westward into the coarser grained alluvial plain deposits of the lower part of the Indianola Group (Witkind and others, 1986).

The Mowry Shale was previously considered to be of late Albian age. However, Cobban and Kennedy (1989) correlated Metengonoceras from the Mowry to those found in known lower Cenomanian rocks in the Gulf Coast area; therefore, they interpreted the Mowry Shale to be of early Cenomanian age. The radiometric age of the Mowry remains the same (96-98.6 Ma; Obradovich and Cobban, 1975, and J.D. Obradovich, oral commun., 1989) inasmuch as these ages were based on radiometric ages of bentonite beds within the Mowry. 
Table 1. Lithologies corresponding to depositional environments in each of the three major depositional settings within the study area

\begin{tabular}{|c|c|c|}
\hline $\begin{array}{l}\text { Depositional } \\
\text { setting }\end{array}$ & $\begin{array}{l}\text { Depositional } \\
\text { environment }\end{array}$ & Lithologic record \\
\hline \multirow[t]{5}{*}{$\begin{array}{l}\text { Marine } \\
\text { foreland basin. }\end{array}$} & 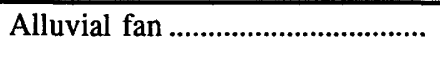 & $\begin{array}{l}\text { Sheet and channel-form conglomerate; less abundant pebbly } \\
\text { sandstone and sandstone; rare siltstone and mudstone. }\end{array}$ \\
\hline & 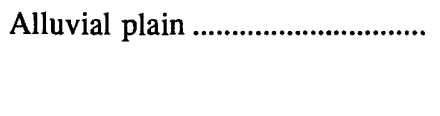 & $\begin{array}{l}\text { Sheet to lenticular sandstone and pebbly sandstone; com- } \\
\text { mon to abundant siltstone and mudstone; common } \\
\text { organic debris. }\end{array}$ \\
\hline & 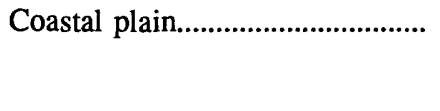 & $\begin{array}{l}\text { Lenticular to tabular sandstone encased in siltstone, mud- } \\
\text { stone, and claystone; abundant to common coal beds and } \\
\text { carbonaceous shale; abundant to common organic debris. }\end{array}$ \\
\hline & Nearshore and coastal marine .... & $\begin{array}{l}\text { Coarsening-upward, sheet to tabular sandstone; interbedded } \\
\text { sandstone and mudstone in lower part; common organic } \\
\text { debris; common marine fossils and trace fossils. }\end{array}$ \\
\hline & Offshore marine & $\begin{array}{l}\text { Dark-gray siltstone, mudstone, and claystone; local cal- } \\
\text { careous mudstone and limestone; local channel-form and } \\
\text { sheet sandstone encased in fine-grained rocks; common to } \\
\text { abundant marine fossils and trace fossils. }\end{array}$ \\
\hline \multirow[t]{6}{*}{$\begin{array}{l}\text { Intermontane } \\
\text { basins. }\end{array}$} & 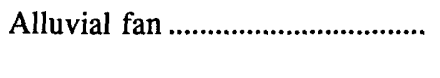 & $\begin{array}{l}\text { Same as in marine foreland basin but red beds common to } \\
\text { abundant. }\end{array}$ \\
\hline & 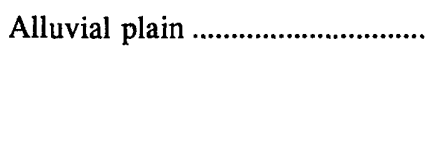 & $\begin{array}{l}\text { Same as in marine foreland basin but red beds common to } \\
\text { abundant; calcareous; variegated mudstone and claystone; } \\
\text { common pedogenic carbonate nodules; rare organic } \\
\text { debris. }\end{array}$ \\
\hline & Wetland & $\begin{array}{l}\text { Calcareous mudstone and claystone; locally common } \\
\text { organic debris; pedogenic features common; common to } \\
\text { rare fossils; thin carbonate beds. }\end{array}$ \\
\hline & 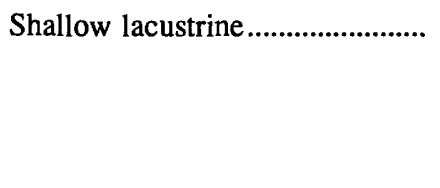 & $\begin{array}{l}\text { Dominantly gray calcareous claystone and carbonate rocks; } \\
\text { less abundant fine-grained sandstone; abundant to } \\
\text { common fossils including charophytes, ostracodes, gas- } \\
\text { tropods, and mollusks; locally common to abundant } \\
\text { organic debris. }\end{array}$ \\
\hline & $\begin{array}{l}\text { Marginal lacustrine-includes } \\
\text { deltaic, delta plain, mudflat, } \\
\text { paludal, and nearshore lacus- } \\
\text { trine settings. }\end{array}$ & $\begin{array}{l}\text { Dominantly gray to tan interbedded sandstone, siltstone, } \\
\text { calcareous mudstone, and carbonate rocks; common to } \\
\text { abundant pisoliths, oolites, and stromatolites; locally } \\
\text { common fossils and organic debris. }\end{array}$ \\
\hline & $\begin{array}{l}\text { Lacustrine-includes nearshore } \\
\text { and open lacustrine settings. }\end{array}$ & $\begin{array}{l}\text { Organic-rich calcareous claystone and mud-supported car- } \\
\text { bonate rocks; less abundant very fine grained sandstone } \\
\text { and siltstone; abundant algal material; disseminated and } \\
\text { bedded saline minerals. }\end{array}$ \\
\hline \multirow{3}{*}{$\begin{array}{l}\text { Volcanic- } \\
\text { dominated } \\
\text { terrain. }\end{array}$} & 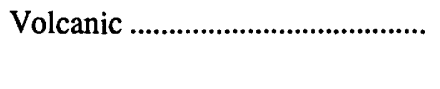 & $\begin{array}{l}\text { Flows; flow breccias, lahars, tuffs, and tuffaceous sedi- } \\
\text { mentary rocks. }\end{array}$ \\
\hline & Alluvial fan and plain...................... & $\begin{array}{l}\text { Conglomerate, sandstone, siltstone, and mudstone com- } \\
\text { posed of volcaniclastic and siliciclastic material. }\end{array}$ \\
\hline & Wetland and shallow lacustrine.. & $\begin{array}{l}\text { Variegated mudstone, carbonate rocks, fine-grained sand- } \\
\text { stone, and siltstone; abundant volcaniclastic material; rare } \\
\text { plant fossils. }\end{array}$ \\
\hline
\end{tabular}

An erosional event subsequent to this phase of early Cenomanian deposition resulted in an unconformity that separates the Mowry Shale from the overlying upper middle Turonian shale of the Frontier Formation on the north side of the Uinta basin. The name Dakota Sandstone has been applied to a sandstone that crops out on the north side of the Uinta basin. This Dakota is of Albian age and is 4-6 m.y. older than a middle and late Cenomanian-age unit that crops out south of the Uinta basin and is also assigned to the Dakota Sandstone. The facies changes between the early
Cenomanian Mowry, Dakota, and Cedar Mountain occur in the subsurface in the Uinta basin. Where the Cedar Mountain Formation crops out in the San Rafael Swell area, palynomorphs recovered from the uppermost part of this unit indicate an Albian age (Tschudy and others, 1984). This palynomorph assemblage does not contain species that are found in Mowry-equivalent rocks (D.J. Nichols, oral commun., 1990). If part of the Cedar Mountain Formation formed in early Cenomanian time, as shown in figure 5, then either palynomorphs of this age have not yet been 

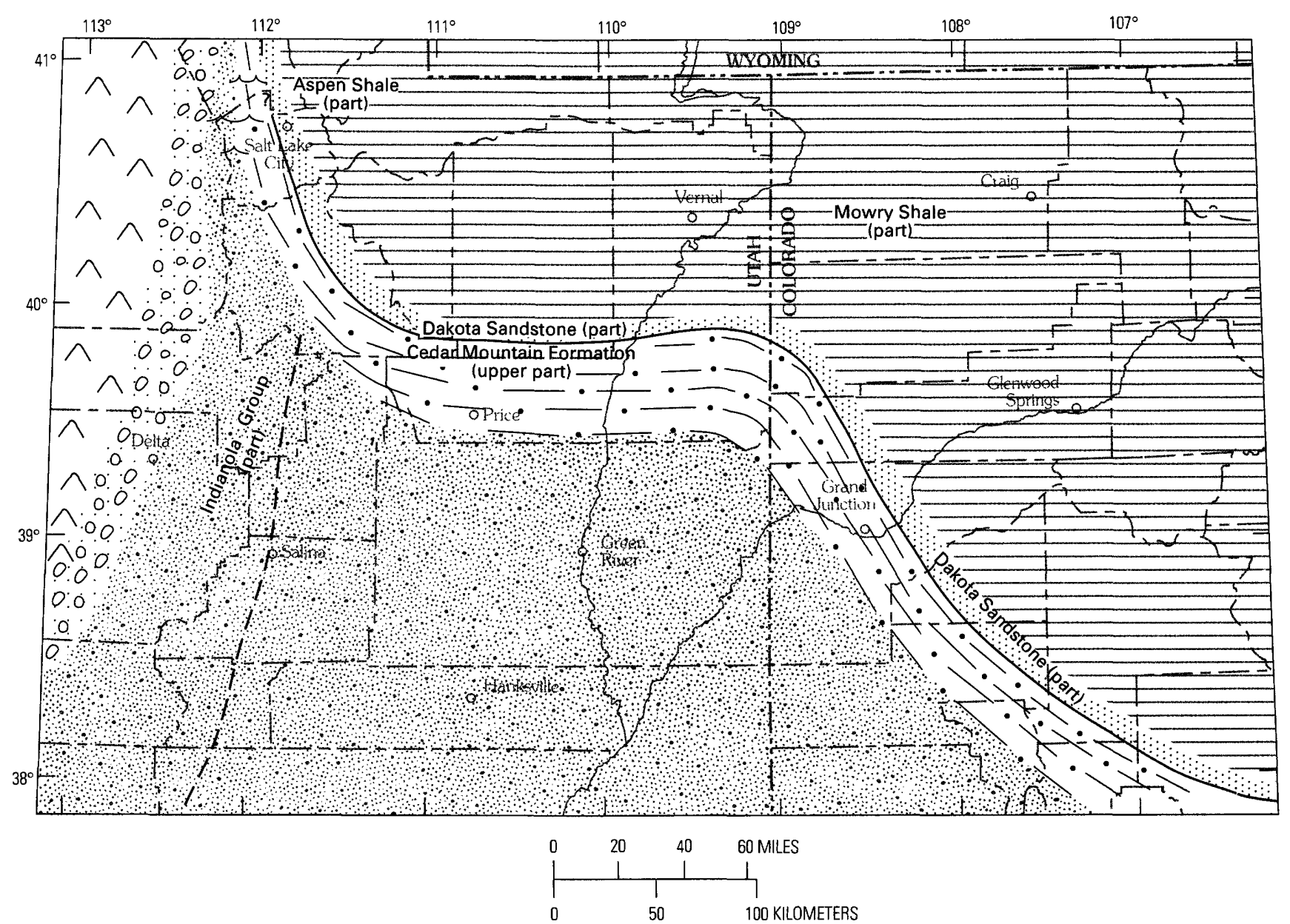

\section{EXPLANATION}
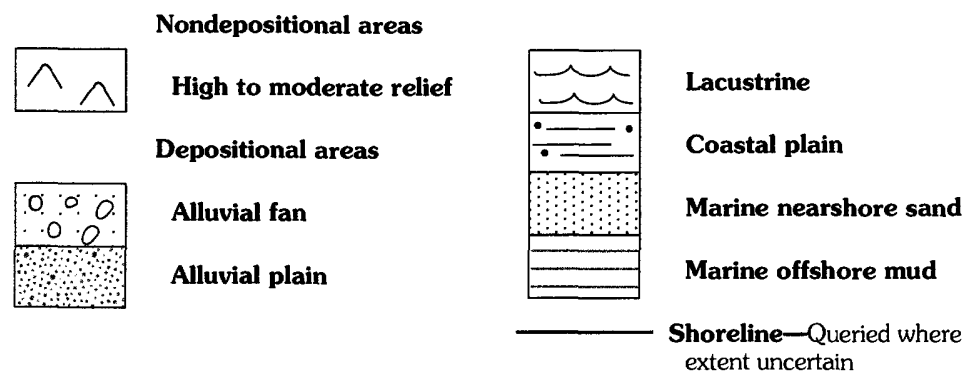

Figure 5. Paleogeographic reconstruction during the early Cenomanian Neogastroplites americanus faunal zone. Relations of the Dakota Sandstone, Mowry Shale, and the upper parts of both the Cedar Mountain and Burro Canyon Formations are based on Molenaar and Cobban (1991). Dashed line marks approximate boundary east of which alluvial plain is mud dominated.

recovered or the early Cenomanian part was eroded during formation of the unconformity that separates the Cedar Mountain from the overlying middle to late Cenomanianage Dakota Sandstone in the San Rafael Swell area.

\section{Early Turonian Vascoceras birchbyi Faunal Zone}

The sea transgressed far into central Utah during this time, and the dominantly north trending coastline that characterized the study area for most of the Late Cretaceous was established (fig. 6). Although this faunal zone coincided more closely with the maximum transgression of the sea farther south in Arizona and New Mexico (Molenaar, 1983), the maximum transgression of the sea in most of the map area occurred later, during the early part of the Collignoniceras woollgari faunal zone (earliest middle Turonian). However, in the southwesternmost part of Utah, the maximum transgression of the sea was during the late Cenomanian Sciponoceras gracile faunal zone (Cobban and Hook, 1984). 

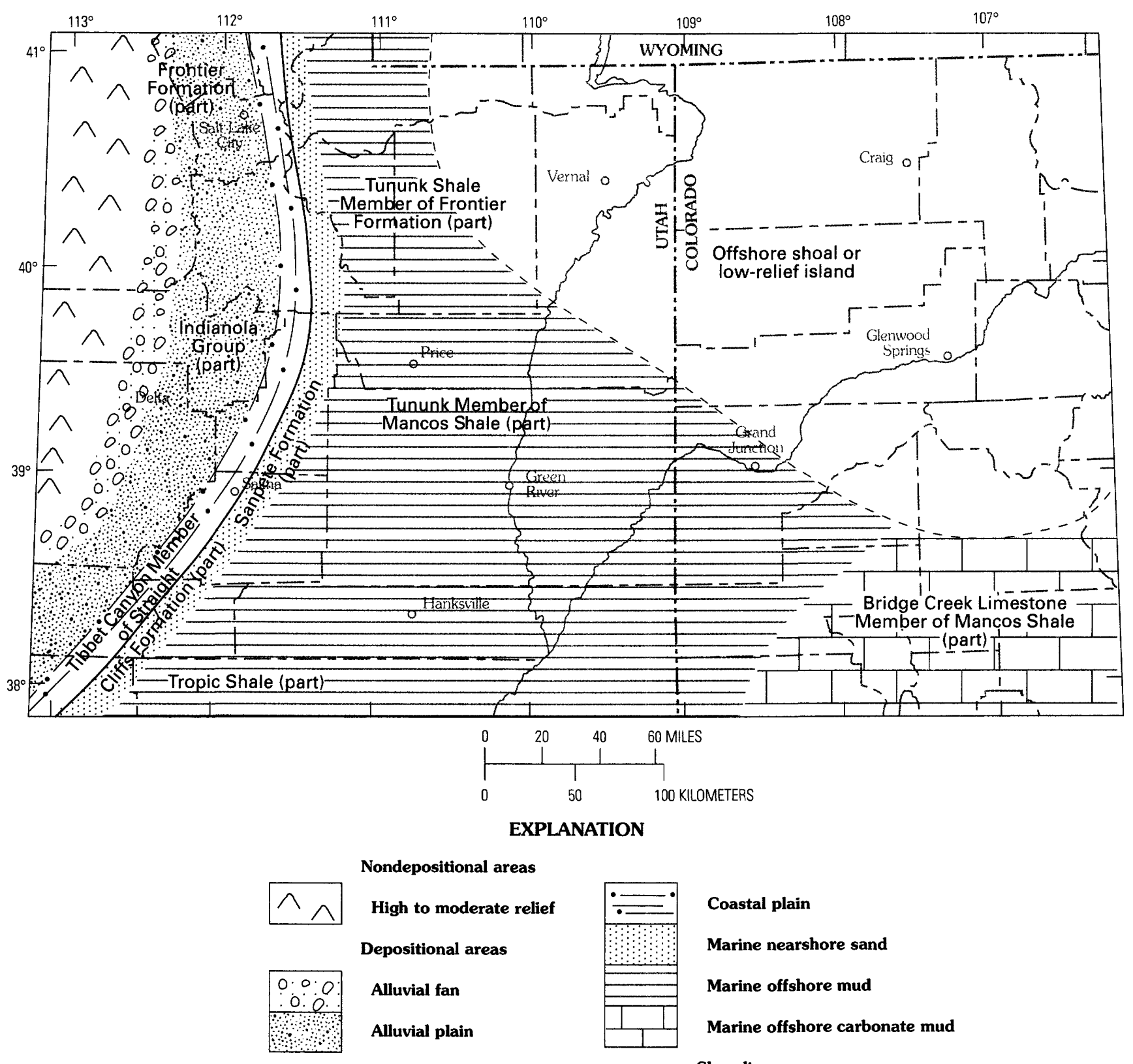

Coastal plain

Marine nearshore sand

Marine offshore mud

Marine offshore carbonate mud

Shoreline

Figure 6. Paleogeographic reconstruction during the early Turonian Vascoceras birchbyi faunal zone. Boundaries of subdivisions within the marine area are modified from Merewether and Cobban (1986) in Colorado and eastern Utah and from Molenaar and Cobban (1991). Unpatterned area to right of dashed line is an offshore shoal or low-relief island; in this area, rocks of this age are absent owing to pre-middle or pre-late Turonian erosion.

During the time of the Vascoceras birchbyi faunal zone and ranging down into the Cenomanian, a large offshore shoal or low-relief island existed in northeastern Utah and northwestern Colorado, according to the interpretation of Molenaar and Cobban (1991). This passive positive area was onlapped by upper Cenomanian through lower middle Turonian marine deposits and finally covered by upper middle Turonian marine deposits. Molenaar and Cobban (1991) have shown a lithofacies map for the early middle Turonian faunal zone of Collig- noniceras woollgari that coincides with part of our map area.

\section{Late Middle Turonian Prionocyclus hyatti Faunal Zone}

The first major regression of the sea started probably in early middle Turonian time in the far western and northwestern parts of the map area, but in most of this area the sea regressed during late middle Turonian time (fig. 7). 

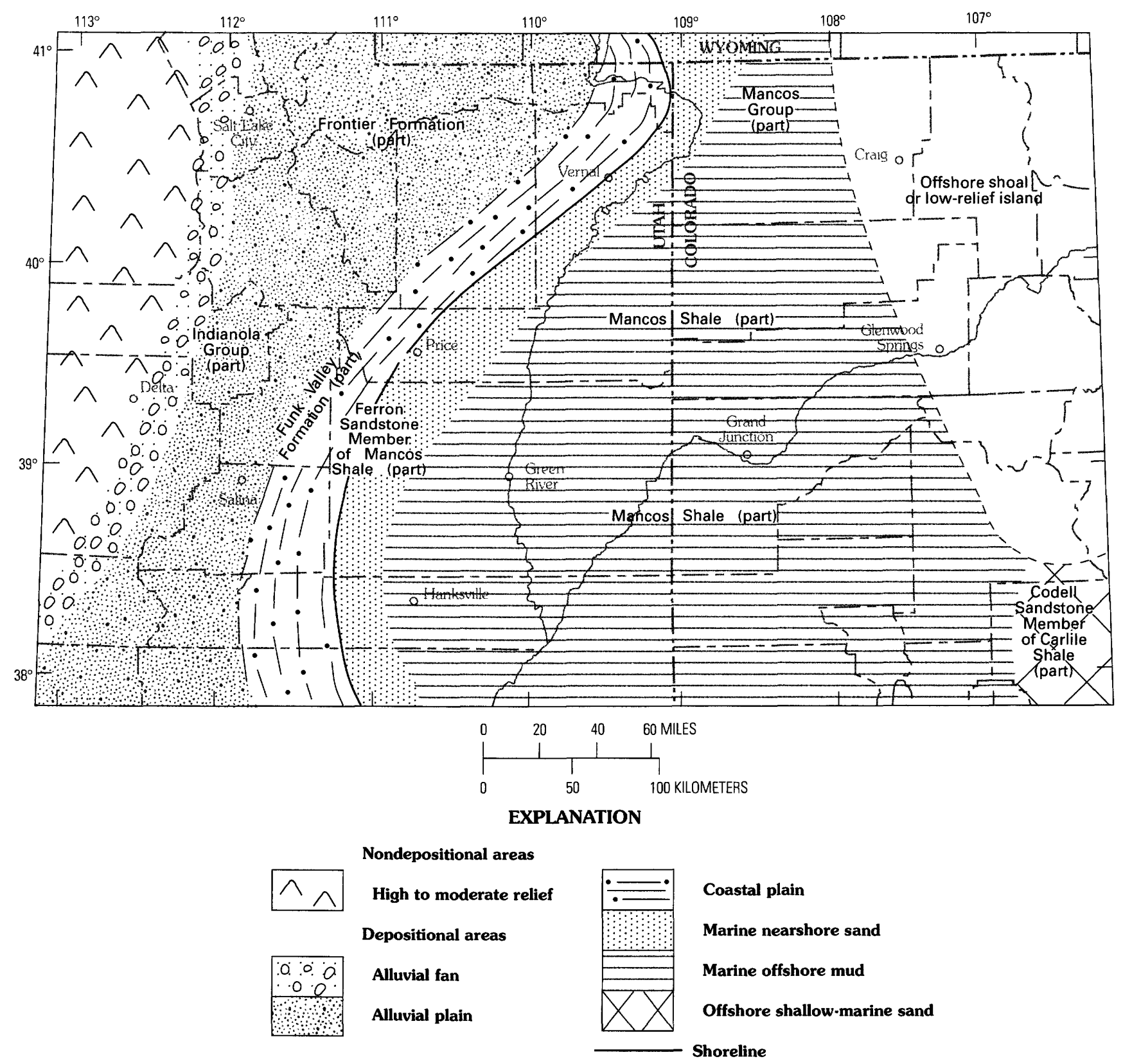

Figure 7. Paleogeographic reconstruction at maximum extent of regression during the late middle Turonian Prionocyclus hyatti faunal zone. Boundaries in Colorado and eastern Utah are modified from Merewether and Cobban (1986). Unpatterned area to right of dashed line may be an offshore shoal or low-relief island; in this area, rocks of this age are absent owing to pre-late Turonian erosion.

The shoreline prograded far to the east in northern Utah producing a northeast-trending shoreline through that area. The shoreline trend becomes more northerly in southernmost Wyoming (Merewether and others, 1983; Merewether and Cobban, 1986). Strata of this age are missing from the unpatterned area that represents an offshore shoal or lowrelief island in the eastern part of the area of figure 7. Whether this missing interval is due to nondeposition on an offshore shoal or to erosion is uncertain; erosion was occurring in other parts of the Western Interior at this time. Weimer and Sonnenberg (1983) showed erosion of upper middle Turonian rocks under the Niobrara Formation in northeastern Colorado. Molenaar and Cobban (1991) have shown lithofacies maps, which coincide with part of our map area, for both this faunal zone and the early late Turonian faunal zone of Prionocyclus macombi. 

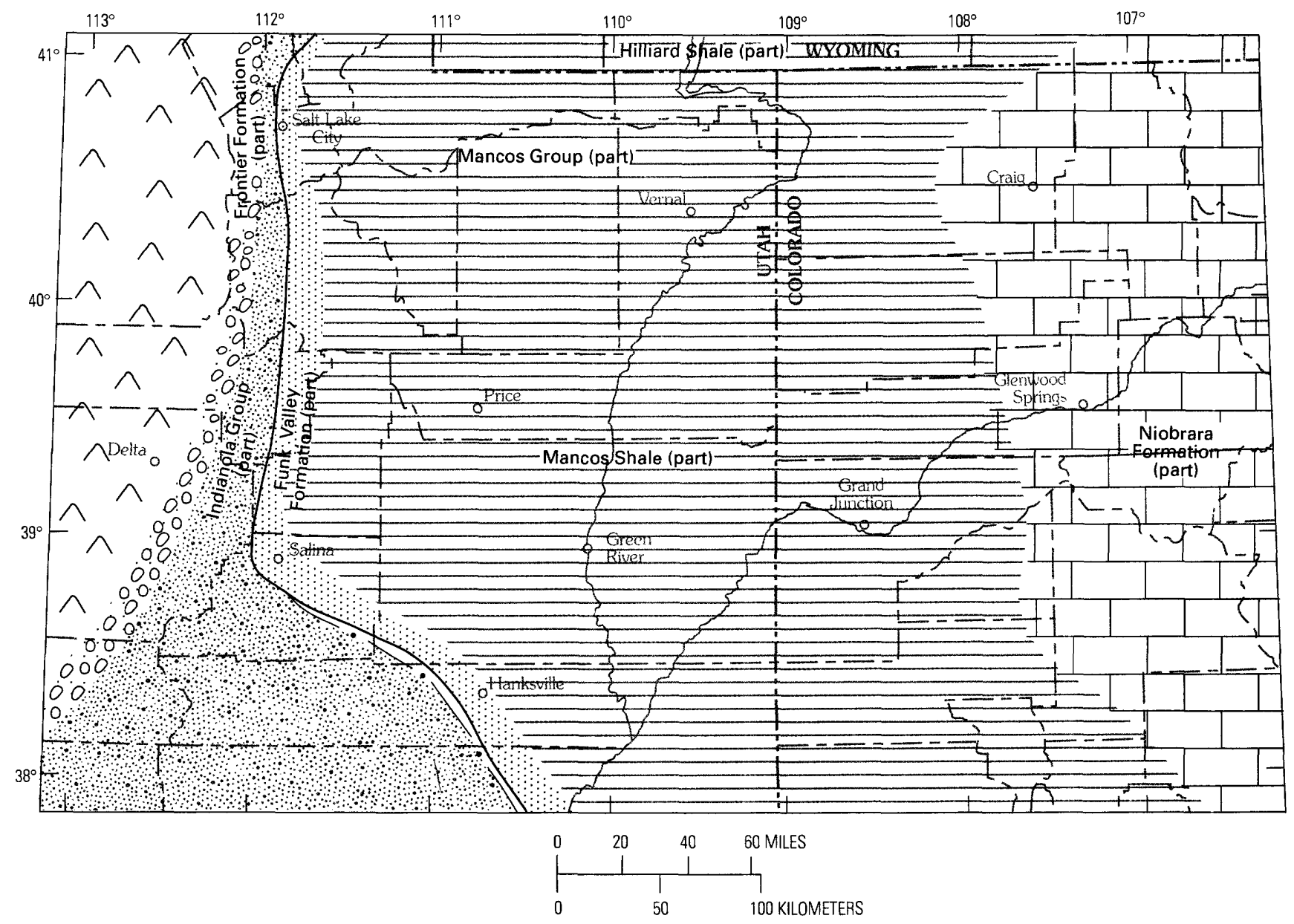

EXPLANATION
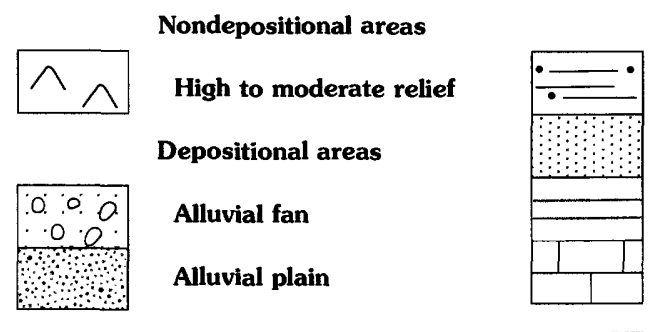

Coastal plain

Marine nearshore sand

Marine offshore mud

Marine offshore carbonate mud

Shoreline

Figure 8. Paleogeographic reconstruction during the middle Coniacian Inoceramus deformis faunal zone. Boundary in western Colorado between marine siliciclastic mud and marine carbonate mud is modified from Merewether and Cobban (1986).

\section{Middle Coniacian Inoceramus deformis Faunal Zone}

A major westward transgression of the sea occurred at this time. As shown in figure 8 , the marine shoreline was near the highlands of the Sevier thrust belt. This relation gave rise to a narrow band of nonmarine rocks representing thick sequences of coarse-grained sediments that were deposited in a north-trending zone undergoing rapid basin- floor subsidence adjacent to the rising highland. The locations of most nonmarine boundaries are uncertain owing to few exposures and postdepositional deformation. A well-defined coastal-plain zone may have only existed locally through the map area at this time, possibly because of the narrow depositional belt between the highlands and the sea.

In the Henry basin area (between the Henry Mountains and the Circle Cliffs uplift on fig. 1) lies an 

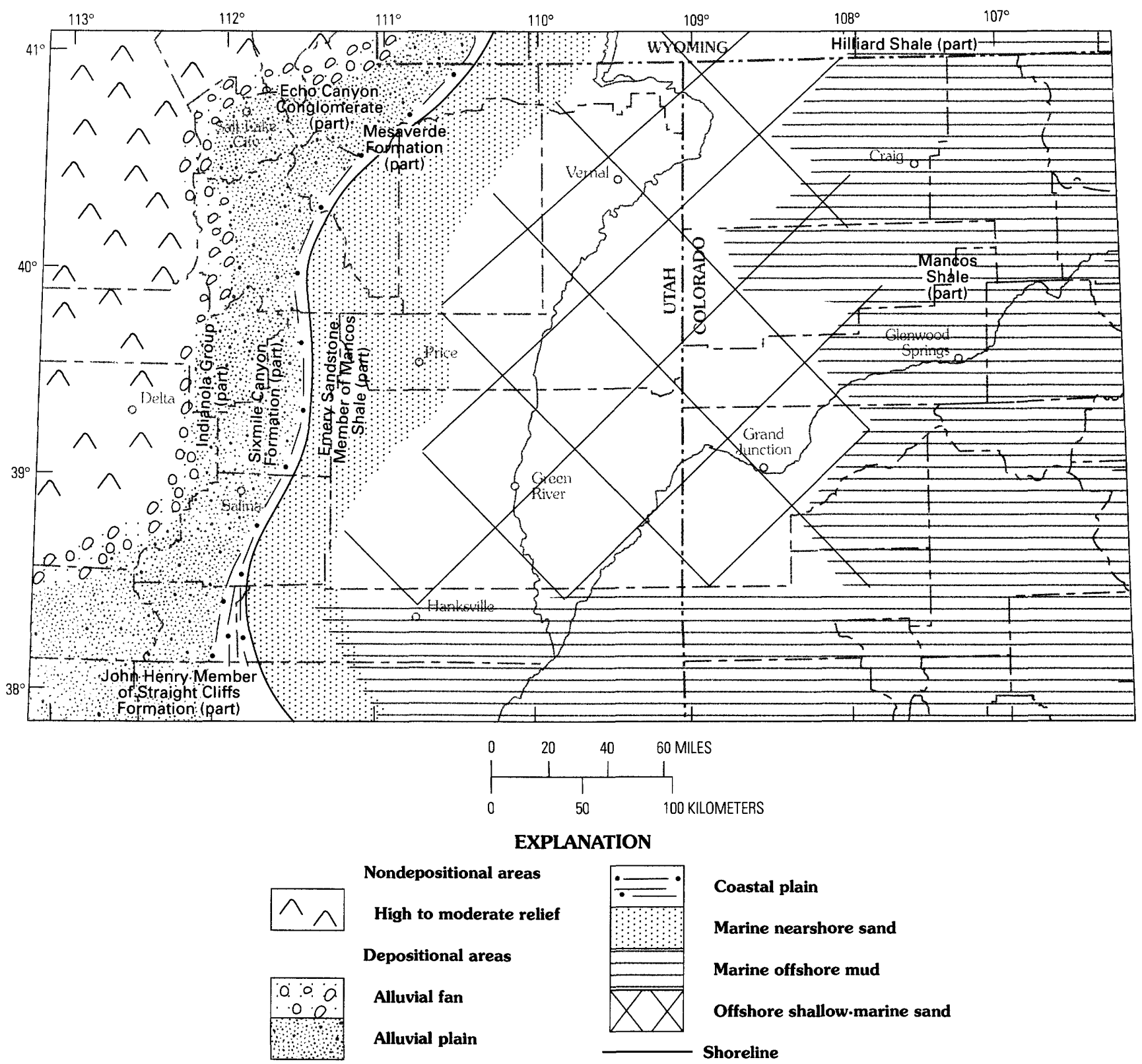

Figure 9. Paleogeographic reconstruction during the late Santonian Desmoscaphites bassleri faunal zone. Area designated as offshore shallow-marine sand also contains offshore mud. Southern areal extent of offshore shallow-marine sand deposition uncertain.

unconformity that encompasses the late Turonian and the lower and middle Coniacian (Peterson and others, 1980). Assuming that this area may have been subaerially exposed during the time represented by this hiatus (Fred Peterson, written commun., 1989), the shoreline south of Salina is shown swinging to the southeast. Although the area west of the southeast-trending part of the shoreline is shown as an area of deposition in figure 8 , it is likely that this area was a sediment bypass surface where no aggradation occurred or that it was actually an area of erosion.

\section{Late Santonian Desmoscaphites bassleri Faunal Zone}

The late Santonian marine shoreline gradually prograded eastward to the west-central part of the study area (fig. 9). Coal-bearing strata associated with this shoreline have been penetrated in drill holes on the Wasatch Plateau. Rocks of this zone are exposed on the plateau's western margin. Interpretations of the ages of these rocks are based 
on palynomorph identifications that are sparse and not sufficiently detailed to permit precise correlation with marine units exposed in eastern Utah and western Colorado.

Sandy strata of the late Santonian Desmoscaphites bassleri faunal zone in central and eastern Utah include the upper parts of the middle to upper Santonian Emery Sandstone Member of the Mancos Shale and their finer grained temporal equivalents (Fouch and others, 1983). Discontinuous sandstone bodies in this zone that are exposed in northeastern and eastern Utah, and less commonly in the western Piceance basin in northwestern Colorado, have been mapped with the Emery (Cullins, 1968; Russon, 1987; Clark, 1928). Their buried counterparts are grouped commonly with the Mancos B, an informal stratigraphic unit of subsurface usage (Fouch and Cashion, 1979; Kellogg, 1977; Cole, 1987) whose age, lithologic composition, stratigraphic contacts, and extent are not defined. In the study area, the Mancos B probably contains strata of early Campanian and Santonian age, including some rocks that are temporally equivalent to the uppermost part of the Emery Sandstone Member of the Mancos Shale exposed east of the Wasatch Plateau. Uppermost Santonian rocks in the western part of the study area most likely include middle and possibly some lower parts of the Sixmile Canyon Formation of the Indianola Group (Fouch and others, 1983) and possibly some beds mapped with the Blackhawk Formation in this same area (Witkind and others, 1987). Equivalents in the northern area would be part of the Echo Canyon Conglomerate; in the southern area they would be part of the John Henry Member of the Straight Cliffs Formation (Peterson and others, 1980; Smith, 1983).

Strata of this age contain an extensive erosion surface that extends from central Utah to northwestern Colorado. This age corresponds to a proposed eustatic sea-level drop at $85 \mathrm{Ma}$ (Haq and others, 1987) that may have exposed much of the marine shelf. Sandstone bodies formed on this erosion surface by both bed-load and storm-generated suspension processes (Swift and others, 1987). Ammonites from the Desmoscaphites bassleri faunal zone occur in strata above and below this erosion surface. Such ammonites have been recovered from the sandy units near Woodside, Utah (sec. 10, T. 18 S., R. 14 E.) and from oolitic, coarse-grained, sandstone bodies near Floy Canyon, about $25 \mathrm{~km}$ east of the Green River (W.A. Cobban, written commun., 1988). The sandy units that encompass the marine scour at Woodside have been included by some workers (Newman, 1985; Swift and others, 1987) in the early Campanian Kenilworth Member of the Blackhawk Formation. Ammonites recovered from both above and below the scour are of the late Santonian Desmoscaphites bassleri faunal zone (W.A. Cobban, written commun., 1988). These fossils confirm that the sandy beds are temporal equivalents and lithic extensions of the uppermost part of the Emery Sandstone Member (as shown in Fouch and others, 1983, their fig. 4) that is exposed east of the Wasatch Plateau and near the northwestern Book Cliffs (Clark, 1928; Cobban, 1976; Fouch and others, 1983; Russon, 1987).

\section{Early Campanian \\ Scaphites hippocrepis I Faunal Zone}

A transgression in latest Santonian and earliest Campanian time caused another landward shift of the shoreline into the western part of the study area. Figure 10, a reconstruction of the Scaphites hippocrepis I faunal zone during earliest Campanian time, illustrates the initial stage of gradual shoreline regressions that eventually resulted in the withdrawal of the seaway from most of the Utah part of the study area by late Campanian time. This systematic regression may be a response to either slowing of basin subsidence along the western margin of the Cretaceous sea in Utah or an increase in clastic sediment supply from the west.

The best dated unit in the region is the Panther Tongue, the lowest member of the Star Point Sandstone in the westernmost Book Cliffs and northeasternmost Wasatch Plateau. Younger members of the Star Point have yielded fossils whose interpreted ages are not precise enough to assign them to a marine molluscan faunal zone. However, Fouch and others (1983) assigned the Panther to the Scaphites hippocrepis I faunal zone based on marine ostracodes that are interpreted to correspond to this zone.

Recovery of age-diagnostic ammonites and palynomorphs from upper Campanian rocks in the map area is rare. As a result, the association of stratigraphic units in the area is based on comparisons to the dated Star Point. No diagnostic marine fossils have been identified from the Muley Canyon Sandstone Member of the Mancos Shale of Smith (1983) in the Henry basin, but Peterson and others (1980), and Smith (1983) have suggested that the Muley Canyon may be the homotaxial equivalent to the Star Point of the northern Wasatch Plateau and western Book Cliffs. However, its assignment to the Scaphites hippocrepis I faunal zone is less certain. In the eastern part of the map area, some beds commonly grouped with the Mancos B are likely to be of the $S$. hippocrepis I faunal zone.

An unconformity probably related to local tectonism and corresponding to much of the Campanian is present in nonmarine rocks adjacent to the thrust belt in southwesternmost Wyoming and north-centralmost Utah (Jacobson and Nichols, 1982). The Echo Canyon Conglomerate contains palynomorph assemblages of Coniacian to Santonian age, and the overlying Hams Fork Conglomerate Member of the Evanston Formation contains palynomorphs of late Campanian to early Maastrichtian age. This hiatus would correspond approximately to the zones of Scaphites hippocrepis $I$ through Baculites scotti (fig. 3). 


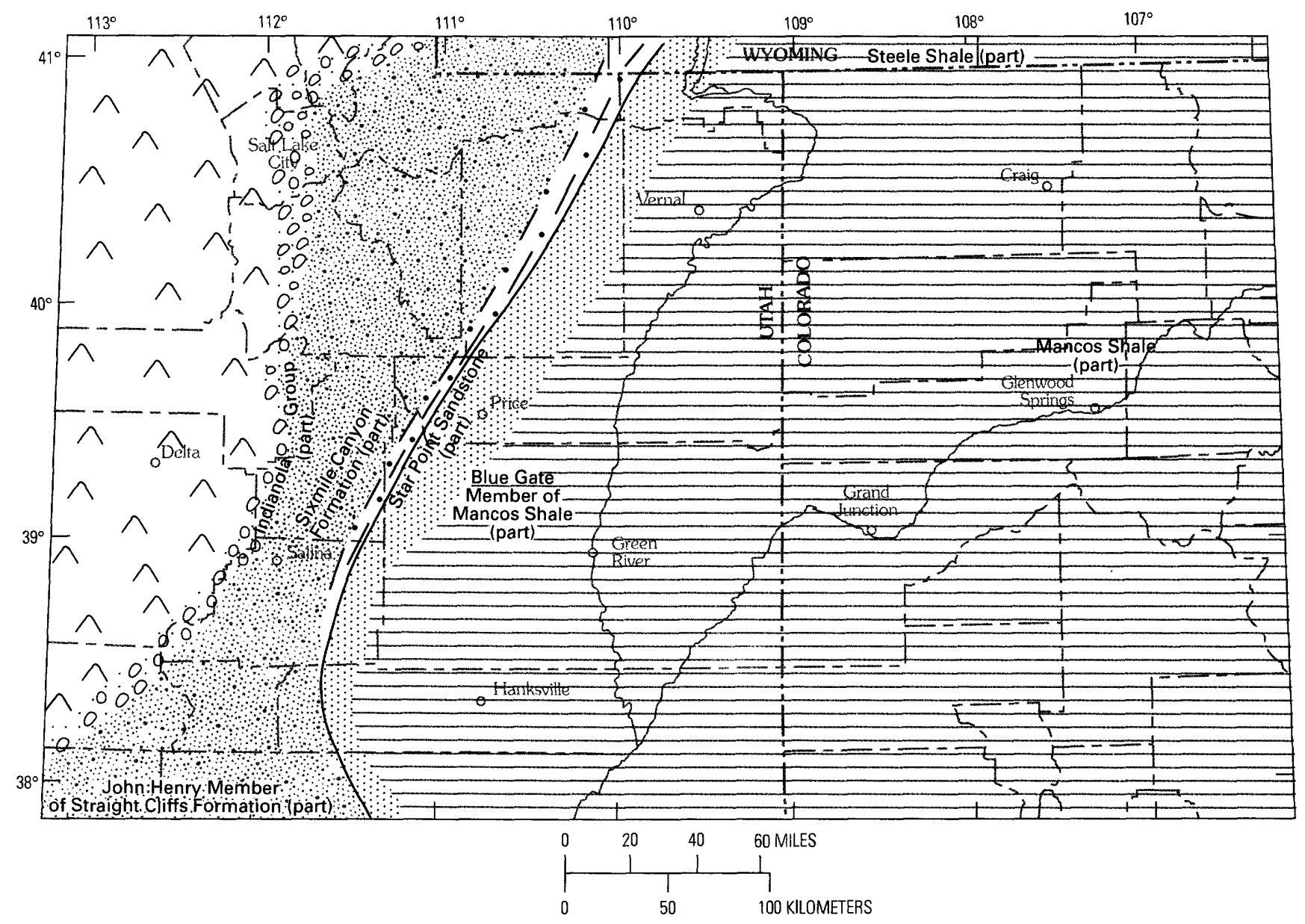

EXPLANATION

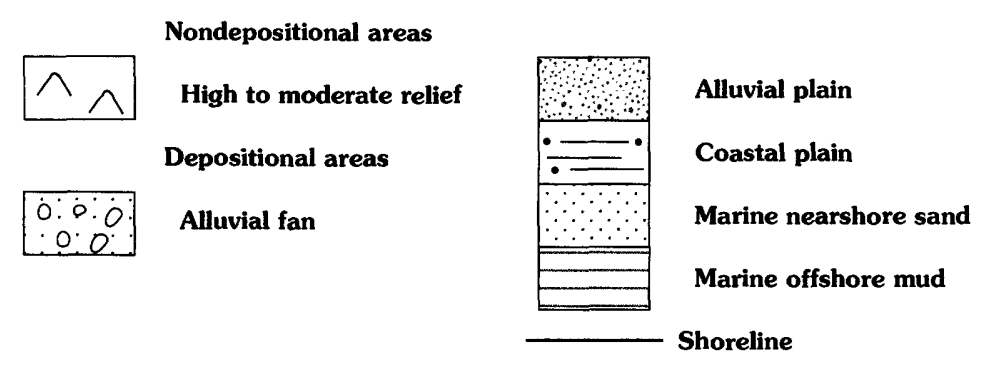

Figure 10. Paleogeographic reconstruction during the early Campanian Scaphites hippocrepis I faunal zone.

\section{Late Early Campanian Baculities mclearni Faunal Zone}

During the late early Campanian, continental facies extended from the western and central Utah highlands east to the marine shoreline, a distance that generally exceeds $100 \mathrm{~km}$ (fig. 11). Prior to the late early Campanian, the alluvial and coastal plain ranged from 40 to $60 \mathrm{~km}$ in width in central Utah. The widening of the band of nonmarine strata of this zone perhaps signals both a decrease in the rate in basin subsidence in central Utah and the eventual withdrawal of the seaway from the Utah part of the Cretaceous landscape. Coarse-grained beds of central Utah are a part of the undifferentiated Indianola Group and the Sixmile Canyon Formation of the Indianola Group. These latter units in turn grade into the Kenilworth Member of the Blackhawk Formation east of the Wasatch Plateau and in the western Book Cliffs, and into the Mancos Shale of eastern Utah and Colorado (Fouch and others, 1983). In the southern part of the area, western nonmarine sedimentary facies are generally assigned to the Wahweap Formation, most of which grades eastward into the nonmarine Masuk Formation (Eaton, 1990) in the Henry Mountains region. Near the thrust belt in the northernmost part of the map area, rocks of this age are not preserved. The reconstruction shows this to be a depositional area because 

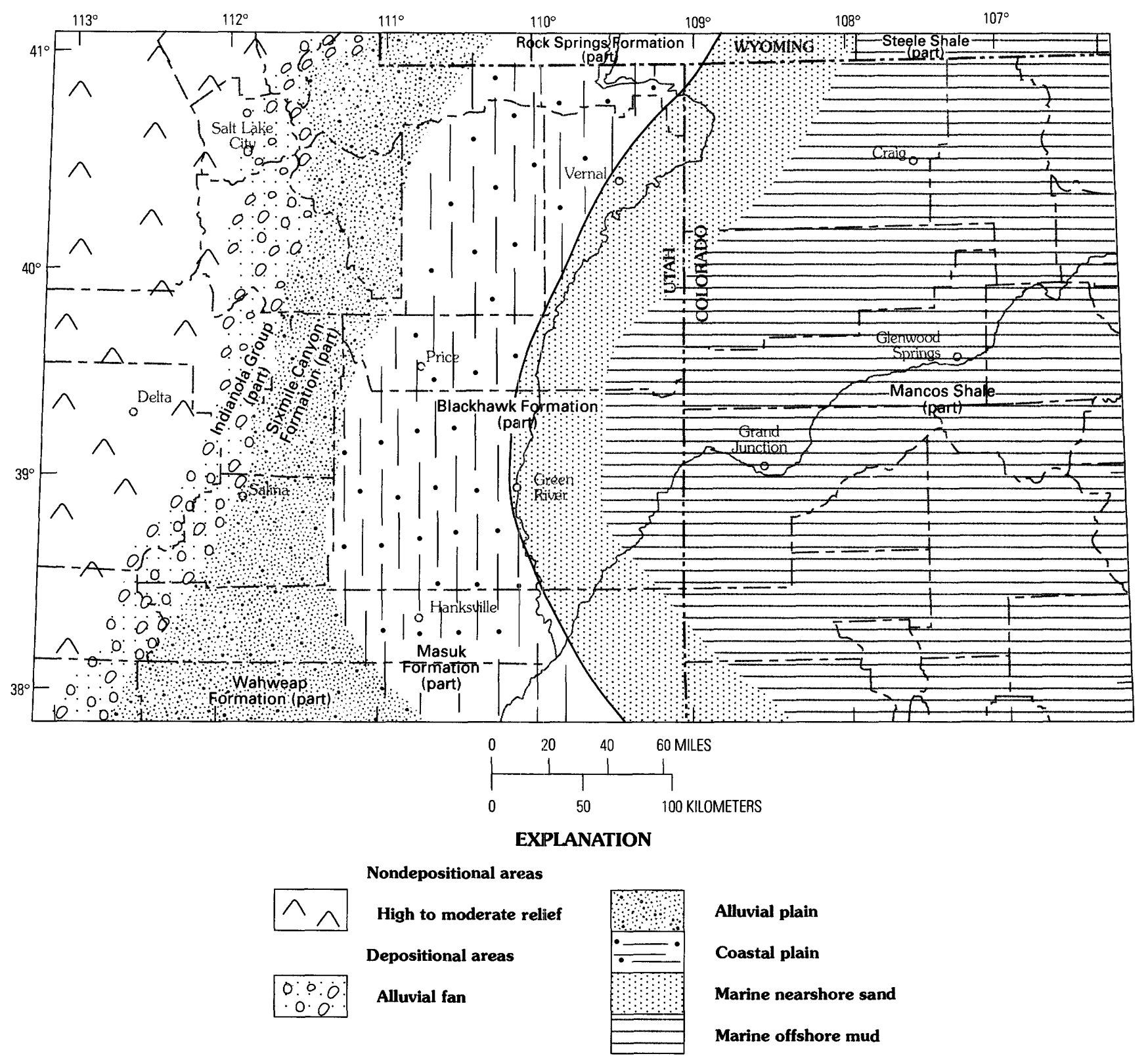

Alluvial plain

Coastal plain

Marine nearshore sand

Marine offshore mud

Shoreline

Figure 11. Paleogeographic reconstruction during the late early Campanian Baculites mclearni faunal zone. The Rock Springs Formation contains pollen assemblages that are equivalent to the Baculites obtusus faunal zone; therefore, this unit may or may not contain equivalents of the B. mclearni zone (D.J. Nichols, oral commun., 1989).

post depositional stripping probably accounts for the absence of these rocks.

\section{Early Late Campanian Baculites asperiformis Faunal Zone}

For the regressive phase that began in the early Campanian, the sea reached its easternmost position during the early late Campanian (fig. 12). The shoreline trend in northwestern Colorado and southern Wyoming is based on Zapp and Cobban (1960), Gill and Cobban (1973), Gill and Hail (1975), and Johnson (1989). In southeastern Utah, the shoreline was east of the Henry Mountains (Peterson and others, 1980). The shoreline through southeastern Utah is located so that it connects with the shoreline shown for this time interval in the San Juan Basin of northwestern New Mexico (Molenaar, 1983). The location of the alluvial plain-coastal plain boundary is based on Van de Graaff (1972) and Gill and Hail (1975). 


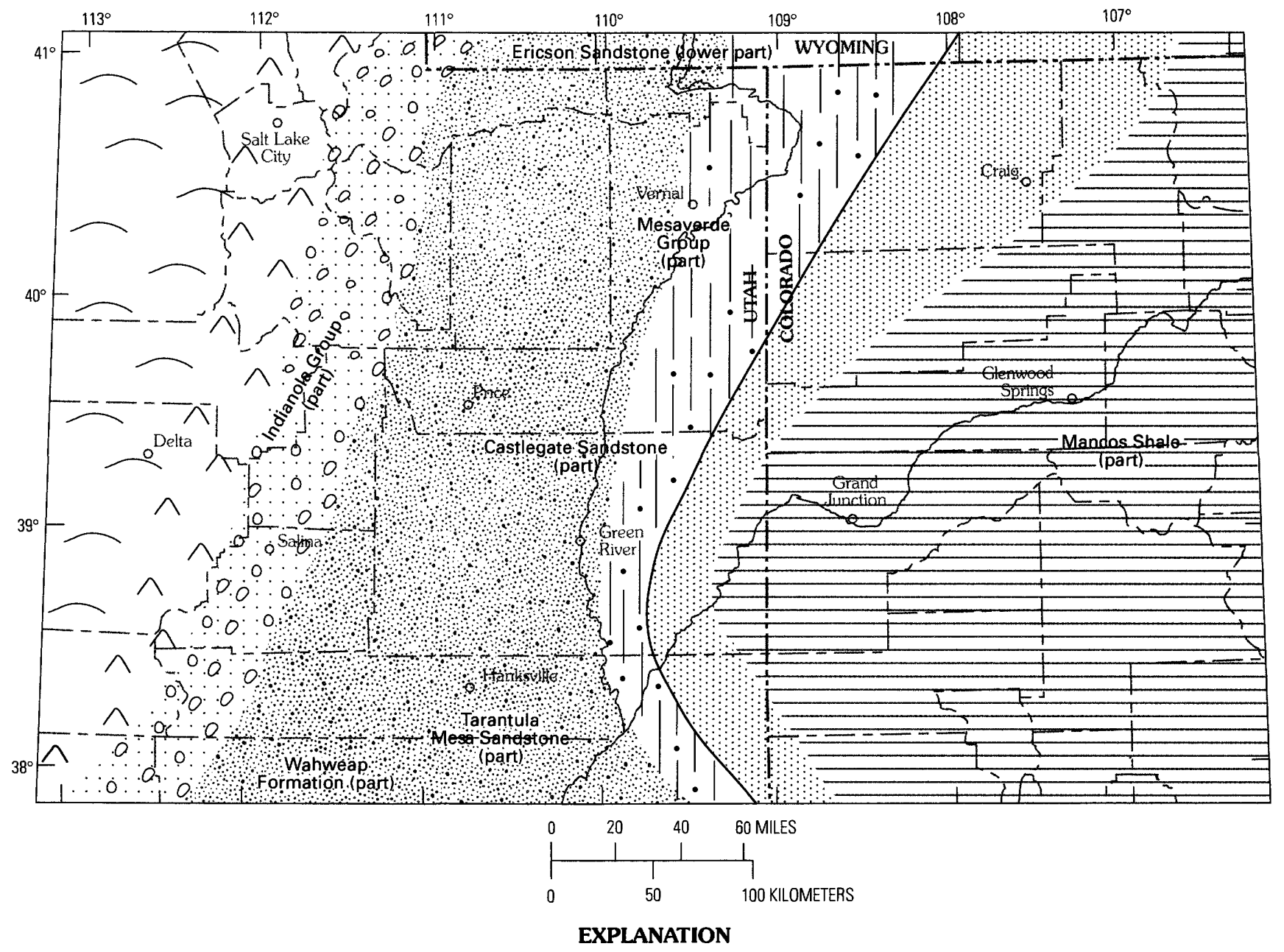

Nondepositional areas
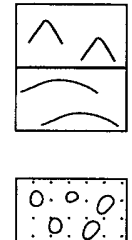

High to moderate relief

Moderate to low relief

Depositional areas

Alluvial fan

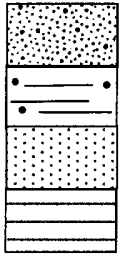

Alluvial plain

Coastal plain

Marine nearshore sand

Marine offshore mud

Shoreline

Figure 12. Paleogeographic reconstruction during the early late Campanian Baculites asperiformis faunal zone.

This latest phase of regression was accompanied by an influx of coarse sediment from the Sevier thrust belt. Regionally extensive, sheetlike strata deposited on the alluvial plain are easily correlated. However, correlation of the alluvial-plain and alluvial-fan rocks is less certain because these rocks cannot be physically traced into each other, outcrops of the alluvial-fan facies are rare, ages of these nonmarine rocks are not tightly constrained, and eastward-propagating thrusting and accompanying deformation may have resulted in extensive erosion of the alluvial-fan deposits. In central Utah, Van de Graaff (1972) correlated the alluvial-plain facies of the Castlegate Sandstone to the conglomerates at Red Narrows (T. 9 S., Rs. 4 and 5 E., USM), but Fouch and others (1976) and Ryder and others (1976) included these conglomerates in the North Horn Formation and interpreted them as basin-margin deposits in the younger intermontane basin system. Only on the basis of mineralogy are the upper part of the Sixmile Canyon Formation (Lawton, 1986) and the conglomerates at Bennion Creek (sec. 14, T. 11 S., R. 6 E.) (Ryder and others, 1976) correlated to the Castlegate Sandstone. 

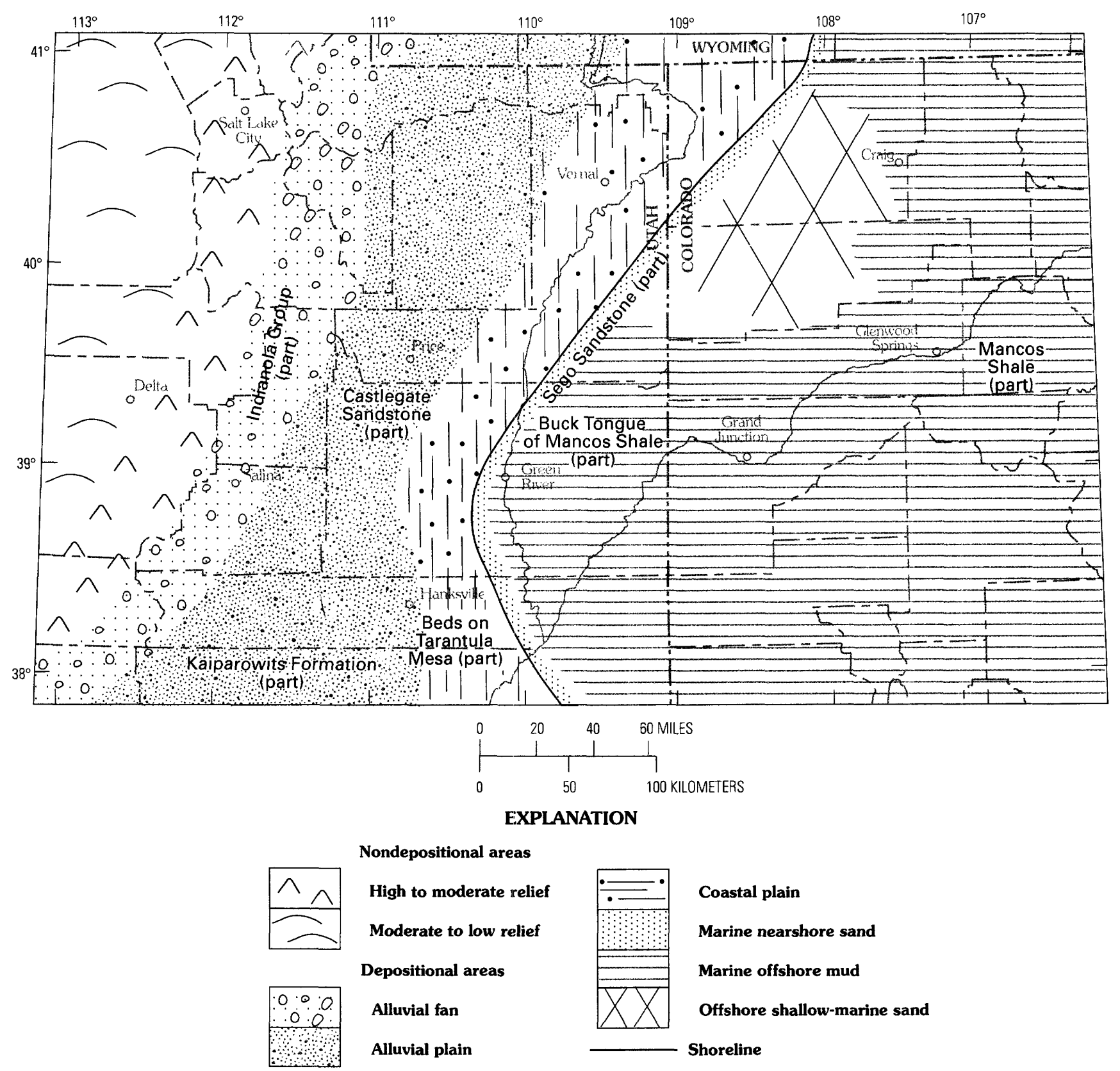

Figure 13. Paleogeographic reconstruction at maximum transgression during the middle late Campanian Baculites perplexus faunal zone. This faunal zone is absent in the Ericson Formation due to a hiatus (D.J. Nichols, oral commun., 1989).

\section{Middle Late Campanian Baculites perplexus Faunal Zone}

The transgression that followed the early through early late Campanian regression reached its maximum landward position, not far west of its preceding maximum regressive position, in middle late Campanian time (fig. 13). The shoreline trends in the northern part of the map area are based on Gill and Hail (1975) and are extended to connect with the shoreline trend in southern Wyoming at this time, shown by Gill and Cobban (1973). In the Green River area, the shoreline and coastal-plain boundaries are based on Fisher and others (1960) and Pfaff (1985). South of the town of Green River, the shoreline swings to the southeast to connect with the shoreline during this transgressive phase in northwestern New Mexico (Molenaar, 1983). As with the 


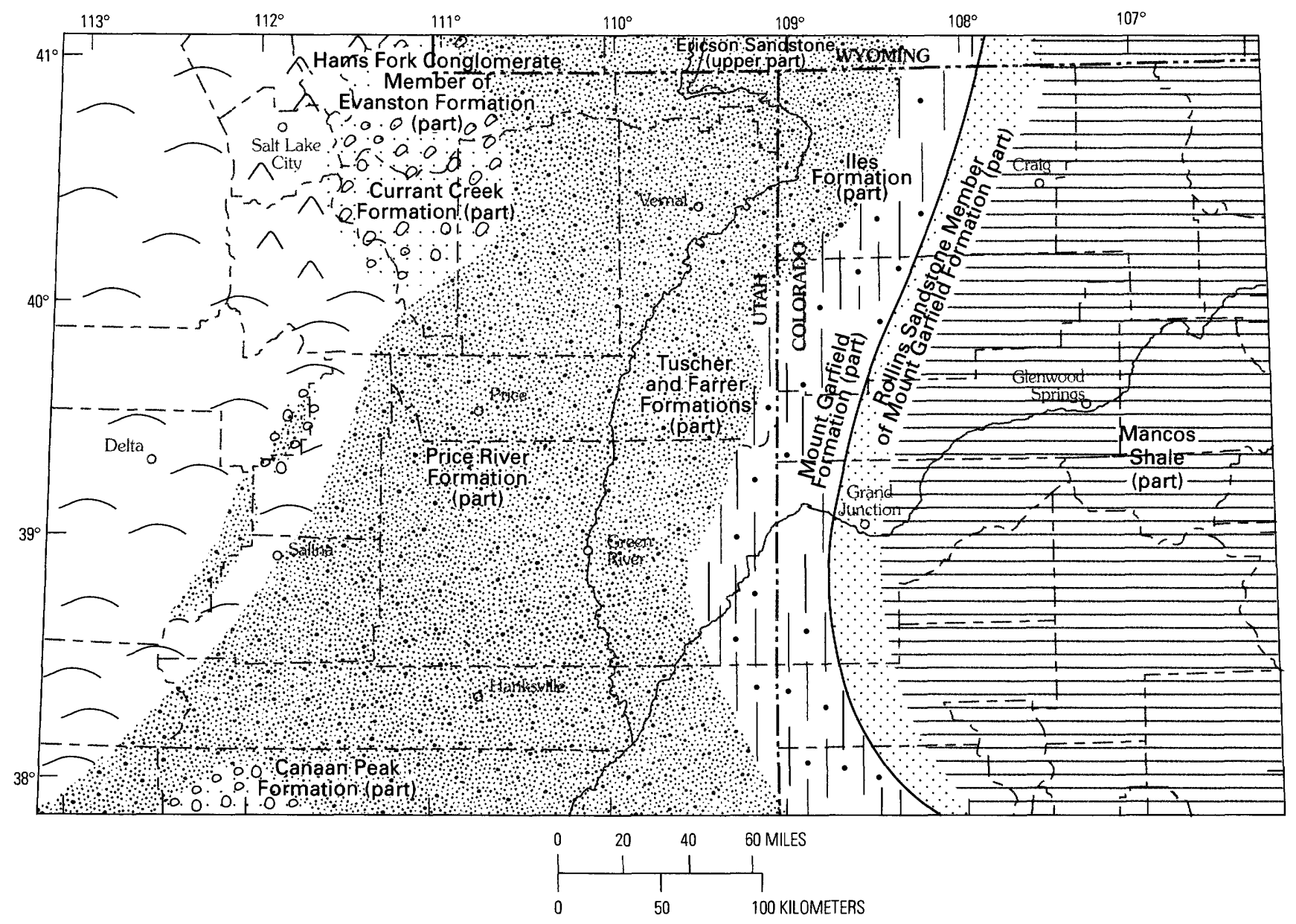

\section{EXPLANATION}
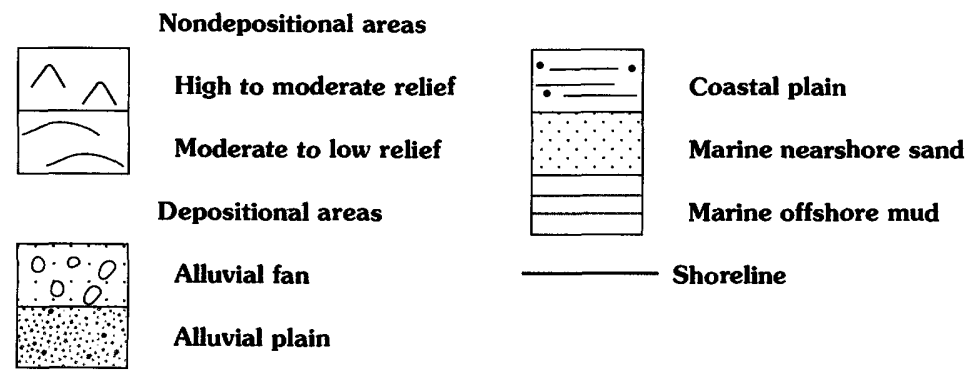

Figure 14. Paleogeographic reconstruction during the late late Campanian Exiteloceras jenneyi faunal zone during the transgression that preceded deposition of the Rollins Sandstone Member and equivalents. Small intermontane (piggy-back) basins near eastern margin of highlands are shown containing only alluvial-plain facies, but alluvial-fan and wetland facies also exist.

alluvial facies of the Baculites asperiformis zone, the correlatives and boundary between the alluvial-fan and alluvial-plain deposits during the $B$. perplexus zone are uncertain.

\section{Late Late Campanian Exiteloceras jenneyi Faunal Zone}

Following the middle late Campanian transgression, the sea's eastward regression during the remainder of the Cretaceous was punctuated by minor transgressions. The reconstruction in figure 14 shows the paleogeography during the minor transgression that preceded deposition of the Rollins Sandstone Member of the Mount Garfield Formation and equivalents. The position of the shoreline is the landward limit of marine deposits associated with the Rollins Sandstone Member (Johnson, 1989). The landward limit of the Cameo coal zone delineated by Johnson (1989) is used as the boundary between the coastal and alluvial plain.

The paleogeography along the eastern margin of the Sevier thrust belt changed significantly from the previous 
Cretaceous patterns of alluvial fans fringing this margin everywhere. Alluvial fans fringing the highlands appear to be confined to the northern part of the map area. Here, the lower part of the Currant Creek Formation and the Hams Fork Conglomerate Member of the Evanston Formation have palynomorph assemblages of latest Campanian to early Maastrichtian age (Jacobson and Nichols, 1982; Nichols and Bryant, 1986; Bryant and Nichols, 1988). The geometry of the alluvial-fan area is speculative. Locally, only the lower $100 \mathrm{~m}$ of the Currant Creek has yielded age-diagnostic pollen, so both the position of the Cretaceous-Tertiary boundary within this unit and the lateral extent of the Cretaceous part of this unit are unknown. Isby and Picard (1983) interpreted the lower part of the Currant Creek to have formed during thrusting in the Sevier thrust belt and the upper part to have formed later during uplift of the Uinta Mountains.

In the Wasatch Plateau and the Utah Book Cliffs areas (fig. 1) occurs a change in paleocurrent directions from easterly in early late Campanian time to northeasterly and northerly in late late Campanian time. A change from dominantly quartzose to more feldspathic mineralogy accompanies the paleocurrent change and indicates that the sediment source area had changed from the thrust belt on the west to areas farther southwest that may or may not have been part of the thrust belt (Lawton, 1986; Franczyk and others, 1990). The Canaan Peak Formation, which crops out in the southwestern part of the map area, contains palynomorphs of late Campanian age in the lower part (Bowers, 1972), is mineralogically similar to the Price River, Farrer, and Tuscher Formations farther to the north, and shows similar paleocurrent directions to these units (P.M. Goldstrand, written commun., 1990).

In the southwestern part of the Wasatch Plateau, deposits of the alluvial-plain facies onlap a structural high (Stanley and Collinson, 1979). Farther west, on the Gunnison Plateau, there are Upper Cretaceous and Paleocene rocks that have been correlated to rocks east of this structural high. But based on depositional facies relations and paleocurrent trends, Lawton (1989; written commun., 1989) has interpreted this Gunnison Plateau sequence to have been deposited in small intermontane basins (piggyback basins) that formed on the thrust allochthon possibly as early as latest Campanian time but definitely by Maastrichtian time. The number, dimensions, and distribution of these intermontane basins that formed on the allochthon have not been completely defined; thus, they are illustrated schematically on the reconstructions.

The entire area east of the south half of the thrust belt is shown as an alluvial plain. However, palynomorph samples collected $3 \mathrm{~m}$ below the top of the Cretaceous section along the Book Cliffs east of the Green River belong to the lower part of the Aquilapollenites quadrilobus Interval Zone of Nichols and others (1982) and are no younger than middle late Campanian (Franczyk and others, 1990).
These samples were collected from $400 \mathrm{~m}$ and more above rocks that contain fauna from the middle late Campanian Baculites perplexus faunal zone, which indicates that deposition continued after the time of $B$. perplexus. During Exiteloceras jenneyi faunal zone time in the southern part of the alluvial-plain area, sediments were deposited and subsequently eroded, or else this area was a bypass surface on which rivers flowed but did not aggrade.

\section{Early Maastrichtian Baculites reesidei Faunal Zone}

During the early Maastrichtian, the seaway remained east of the study area during all but two brief periods. The first incursion occurred in Baculites reesidei faunal zone time when the Twentymile Sandstone Member of the Williams Fork Formation formed (fig. 15). The second incursion occurred in Baculites clinolobatus faunal zone time when the Lion Canyon Sandstone Member of the Williams Fork Formation formed (fig. 16). Figure 15 shows the shoreline at the western limit of the marginal marine Twentymile Sandstone Member. The western limit of the coal group overlying the Twentymile Sandstone Membervariously named the upper coal group of the Williams Fork Formation (Fenneman and Gale, 1906), the Paonia Shale Member of the Mesaverde Formation (Lee, 1909), or the Paonia Shale Member of the Williams Fork Formation of the Mesaverde Group (Collins, 1976)-defines the landward limit of the coastal plain.

An alluvial-fan complex is shown fringing the highlands in the northwestern part of the map area because of the latest Campanian to early Maastrichtian age inferred from palynomorph assemblages obtained from the lower part of the Currant Creek and the Hams Fork. D.J. Nichols (in Franczyk and others, 1990) interpreted a palynomorph assemblage obtained from a core of uppermost Cretaceous rocks in the eastern Uinta basin to be of early Maastrichtian age. Therefore, an alluvial plain is shown east of the alluvial-fan area. However, no palynomorph assemblages this young were recovered from the uppermost part of the Cretaceous along the Book Cliffs (Franczyk and others, 1990) because of either postdepositional erosion or nondeposition. The latter interpretation is used in the reconstruction because uplift of the San Rafael structure began in latest Campanian or early Maastrichtian time (Fouch and others, 1983; Lawton, 1986; Franczyk and Nichols, 1988), and subsidence may have ceased in the area surrounding the uplift. Franczyk and Nichols (1988) interpreted a thin, southeasterly-derived conglomerate to conglomeratic sandstone unit that occurs at the base of the North Hom Formation in the southern and east-central Wasatch Plateau to have formed in the incipient intermontane basin between the rising San Rafael uplift and the thrust belt. However, palynomorphs have not been recovered from this unit, so an early Maastrichtian age is speculative. 


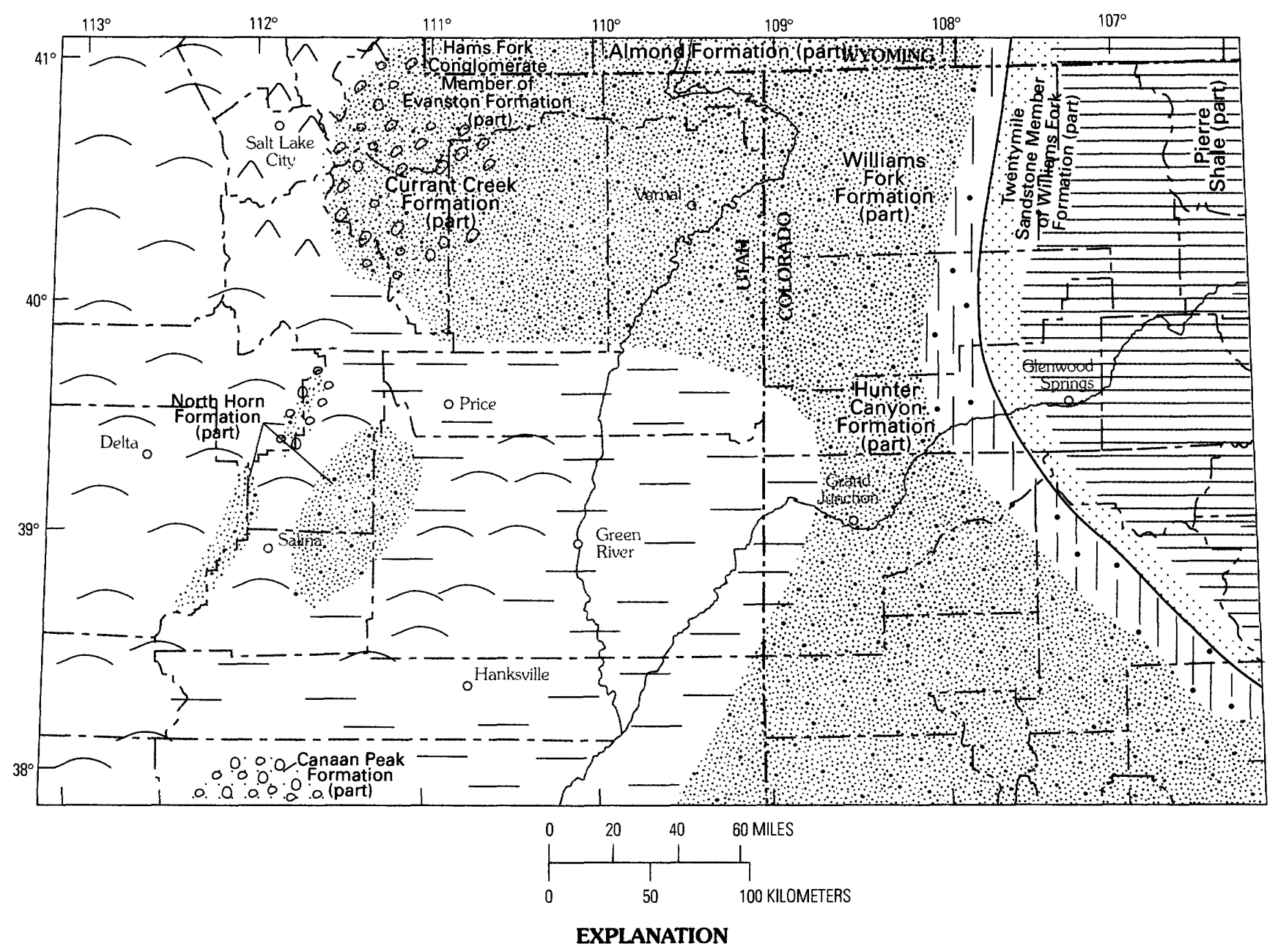

Nondepositional areas

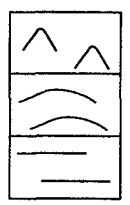

High to moderate relief

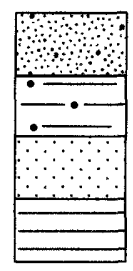

Alluvial plain

Moderate to low relief

Low relief to nonsubsiding

Depositional areas

Alluvial fan

Coastal plain

Marine nearshore sand

Marine offshore mud

\begin{tabular}{|c|}
\hline \\
\hline 0.0 .0 \\
\hline
\end{tabular}

Shoreline

Figure 15. Paleogeographic reconstruction during the early Maastrichtian Baculites reesidei faunal zone. Shoreline is shown at most landward extent of transgression that preceded deposition of the Twentymile Sandstone Member and equivalents. Areas shown as low-relief to nonsubsiding probably had rivers flowing across them and had local wetlands on them.

The Canaan Peak Formation may or may not have formed continuously from late Campanian through early Paleocene time. No Maastrichtian-age palynomorph assemblages have been recovered from the middle part of this unit. The uppermost part of the Canaan Peak is lower Paleocene (P.M. Goldstrand, written commun., 1990). In this early Maastrichtian reconstruction, a small depositional area in the southwestern part of the map area represents
Canaan Peak deposits. Because of postdepositional erosion, the eastern extent of deposition is unknown. The facies within the Canaan Peak do not indicate accumulation in a closed basin (P.M. Goldstrand, written commun., 1990). If the area of aggradation was restricted, rivers flowing eastward and northeastward from this area may have flowed across a bypass surface. 

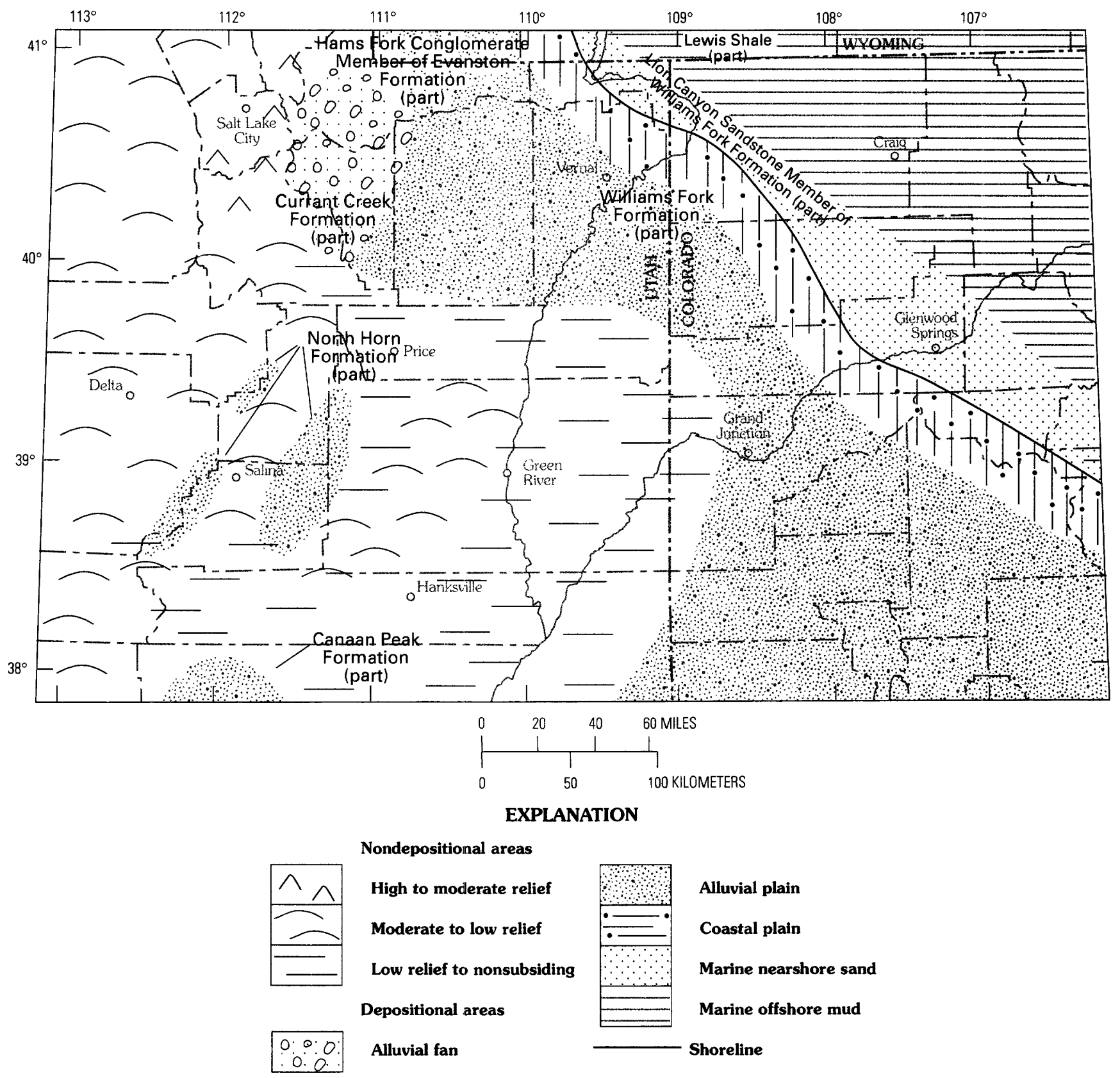

Figure 16. Paleogeographic reconstruction during the middle Maastrichtian Baculites clinolobatus faunal zone. Position of shoreline through most of the study area is from Gill and Cobban (1969). Alluvial section shown landward of coastal plain is identical to that shown for the Baculites reesidei faunal zone reconstruction because the age resolution using palynomorphs is not great enough to distinguish the difference in time that these two faunal zones represent.

\section{Middle Maastrichtian Baculites clinolobatus Faunal Zone}

The shoreline trend shifted from predominantly northeasterly to northwesterly during the second Maastrichtian incursion of the sea into the study area (fig. 16). The presence of the mollusk-bearing, marginal-marine Lion Canyon Sandstone Member of the Williams Fork Formation and the coal zone in the Williams Fork that formed landward of the Lion Canyon shoreline establish the position of the shoreline and coastal plain area. However, of the nonmarine strata deposited contemporaneously with this incursion, much has been eroded; additionally, palynology used to date the nonmarine strata cannot distinguish subdivisions finer than early and late Maastrichtian. Therefore, the distribution of the nonmarine paleogeography is uncertain and is shown as the same as for the early Maastrichtian. 

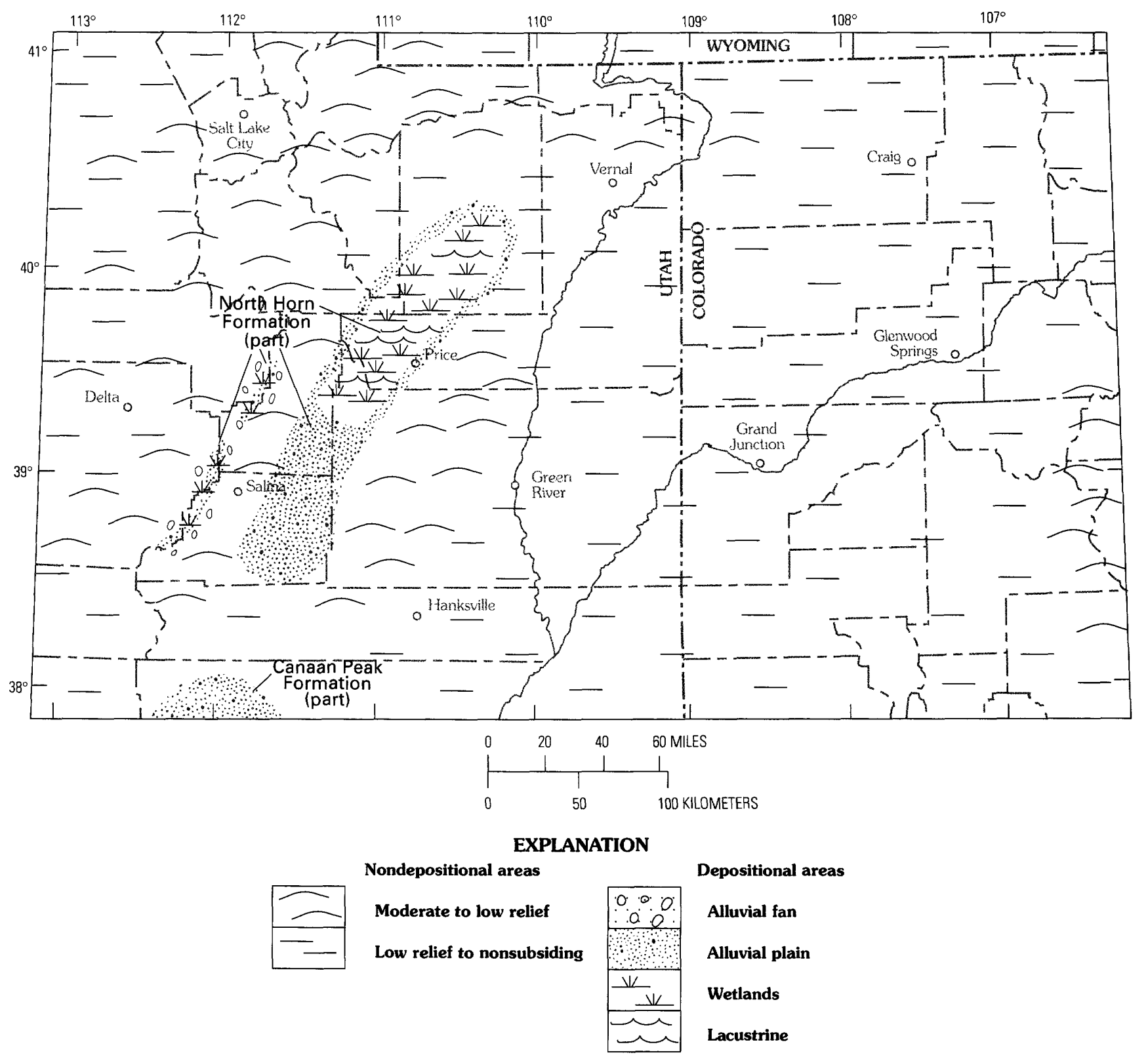

Figure 17. Paleogeographic reconstruction during the late Maastrichtian. Existence of mixed alluvial plain and wetland area in southwestern map area is speculative. Mixed alluvial-fan, alluvial-plain, wetland, and shallow-lacustrine environments existed over much of the depositional areas.

\section{Late Maastrichtian}

From late Maastrichtian time on, the sea had regressed completely from the map area (fig. 17), and the time intervals can no longer be correlated to marine faunal zones. No published accounts mentioning late Maastrichtian-age palynomorph assemblages from the study area exist. J. Zawiskie (oral commun., 1987) reported late Maastrichtianage palynomorphs both from the Gunnison Plateau and from the lower part of the North Horn Formation at the type locality on the Wasatch Plateau. Dinosaur bones also occur in the lower part of the North Horn at the type locality
(Spieker, 1946). A Maastrichtian charophyte assemblage recovered from the base of the North Horn Formation at Price Canyon (sec. 21, T. 12 S., R. 9 E.; Fouch and others, 1987) is similar to global late Maastrichtian-age charophyte assemblages, which suggests a late Maastrichtian age for this assemblage in Price Canyon (R.M. Forester, oral commun., 1989). Based on magnetostratigraphy, Hobbs (1989) inferred latest Maastrichtian deposition on the Gunnison Plateau. These data indicate that late Maastrichtian deposition was restricted to the intermontane basins on the allochthon and west of the San Rafael uplift. Bryant and Nichols (1988) showed the initiation of the main phase of 
movement in the western part of the Uinta uplift to have begun in late Maastrichtian time. The Sawatch uplift in Colorado also became active at this time (Obradovich and others, 1969; Tweto, 1975). Except for the restricted basins and the active uplifts, most of the map area had slight or no relief and was not subsiding.

\section{Middle Paleocene}

The early Paleocene paleogeography probably did not vary greatly from that in the late Maastrichtian. The only published record of early Paleocene-age palynomorphs is from a thin, areally restricted conglomerate and conglomerate sandstone unit, the Dark Canyon sequence of the Wasatch Formation, in the eastern Book Cliffs (Franczyk and others, 1990). Scattered lags of conglomerate that occur locally throughout the map area may have formed adjacent to uplifts in the early or middle Paleocene but do not indicate the initiation of subsidence. Although only early and late subdivisions of the Paleocene are formally recognized, Nichols and Ott (1978) proposed early, middle, and late subdivisions for the Paleocene based on palynomorph assemblages. Our use of middle Paleocene follows that of Nichols and Ott (1978).

In middle Paleocene time, the Uinta and Piceance basins began to acquire their present-day configuration (fig. 18). In the Uinta basin, the primary source of clastic material, based on the occurrence and distribution of conglomerate both in the Currant Creek Formation and in the North Horn Formation at the Red Narrows (T. 9 S., Rs. 4 and 5 E., USM) and Diamond Fork (Tps. 4 and 5 S., Rs. 4 and 5 E., USM) areas, was from the northwest and west margins of the basin. Palynomorphs have not been recovered from the Diamond Fork and Red Narrows outcrops. The upper part of these units intertongues with Paleocene limestone beds (Fouch and others, 1976), but no evidence exists for the age of the lower part.

In the lower part of the North Horn in Price Canyon northwest of Price, Utah, a thick fluvial sandstone sequence has a sharp, probably unconformable contact with the underlying late Maastrichtian part of the North Horn. This sandstone sequence may be the alluvial-plain equivalent of these conglomerates. Middle Paleocene-age palynomorphs were collected from the uppermost part of this sandstone sequence (Fouch and others, 1987), and paleocurrent trends indicate a source to the west and northwest (Franczyk and others, 1989). However, western parts of this alluvial-plain system have not been identified. Well logs from the west-central part of the Uinta basin (Carter Oil Co., J. Burnett \#1, sec. 34, T. 4 S., R. 11 W., USM; Shell Oil Co., Ute Tribal \#1-16D, sec. 16, T. 4 S., R. 9 W., USM) do not show a thick fluvial section in the lower part of the middle Paleocene section. The southwestern part of the Uinta basin contains no well-exposed, continuous, unfaulted outcrops of the Cretaceous through the late Paleocene section. Therefore, the geometry and distribution of the alluvial-plain facies in the lower part of the North Horn in Price Canyon are unknown. Possibly this alluvial-plain facies existed in early middle Paleocene time and was confined to the southwesternmost part of the Uinta basin. The reconstruction in figure 18 shows the alluvial environments confined to the north and west edges of the Uinta basin and the mixed wetland and lacustrine environments throughout most of the basin interior, a distribution that probably existed during most of the middle Paleocene.

Along the Book Cliffs north of the San Rafael uplift, rocks containing middle Paleocene palynomorphs overlie Campanian rocks; and slightly farther east, in the Green River area, upper Paleocene rocks overlie Campanian or, locally, lower Paleocene rocks. In the subsurface of the Uinta basin, Fouch and Cashion (1979) showed the North Horn thinning to the east. Although the easternmost limit of middle Paleocene rocks is not known, the edge of middle Paleocene deposition is shown to be immediately west of the Green River. Within the map area of this report, the southern limits of middle Paleocene deposition are also speculative. Palynomorphs collected from the base of the Pine Hollow Formation, which unconformably overlies the Canaan Peak Formation, indicate these rocks to be lower Paleocene (P.M. Goldstrand, written commun., 1990). Goldstrand (1989) interpreted the Pine Hollow and overlying Claron Formation to have formed in an internally drained basin.

In the Piceance basin, onlapping of the CretaceousTertiary unconformity appears to have begun in middle Paleocene time when a coarse-grained fluvial system spread westward from the trough of the basin. Middle Paleocene palynomorphs have been collected from the lower part of the Paleocene section along both the Grand Hogback, near the structural trough of the basin (Newman, 1974), and the White River in the northern part of the basin (Hail, 1973). Along the western margin of the Piceance basin, the unconformity was not onlapped until near the beginning of the late Paleocene (Johnson and May, 1978, 1980). Coarse pebbles and cobbles, at least partly derived from the Sawatch uplift southeast of the basin (Tweto, 1975), occur throughout much of the middle Paleocene section.

\section{Early Late Paleocene}

In early late Paleocene time in the Uinta basin of northeastern Utah, the area of shallow lakes separated by wetlands expanded; its eastern extent was within a few miles of the crest of the Douglas Creek arch (fig. 19). The deposits formed in these environments compose the Flagstaff Member of the Green River Formation (Fouch, 1976) in the Uinta basin. A deeper, more extensive lake may have begun to form at this time along the depositional axis 

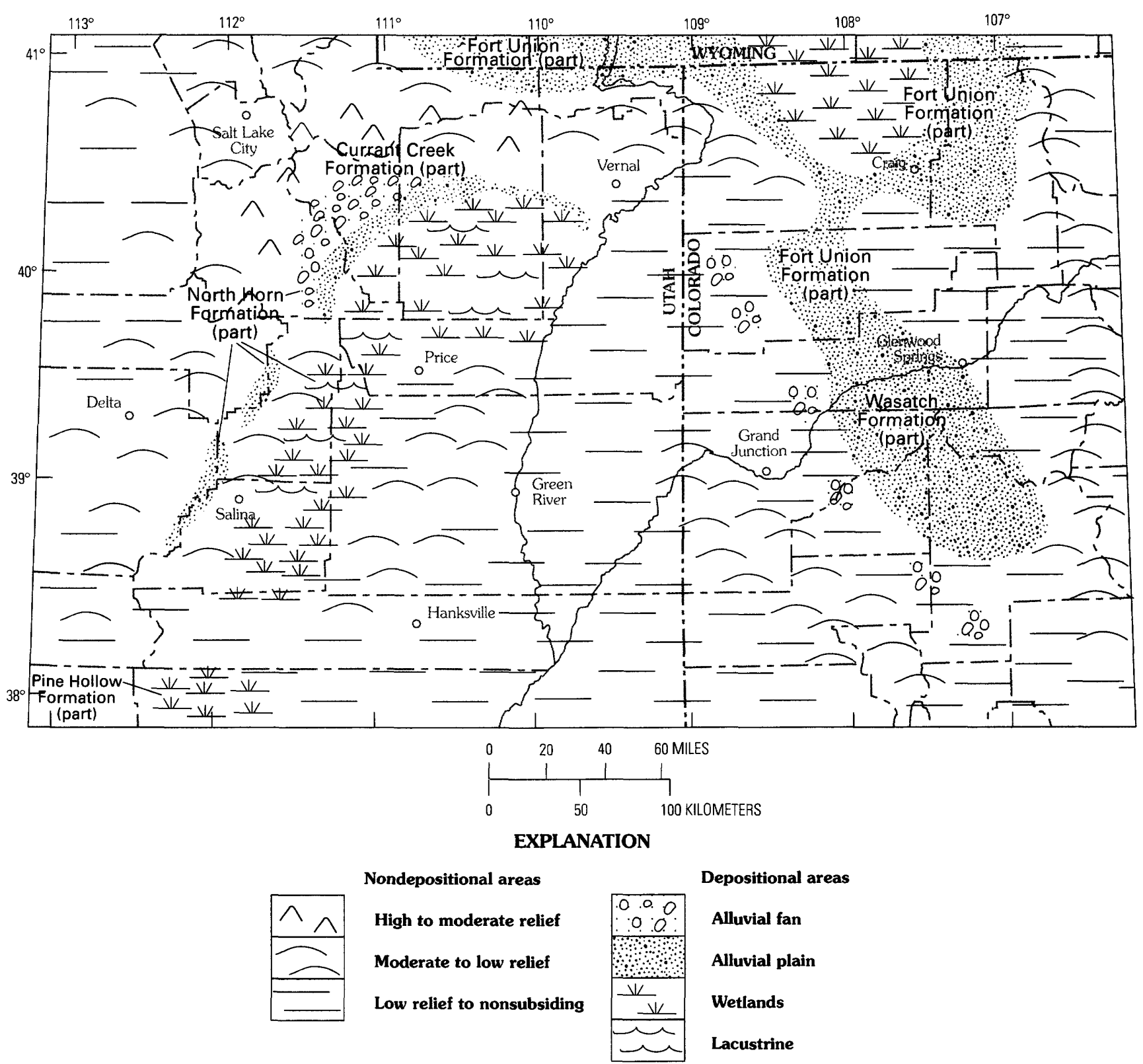

Figure 18. Paleogeographic reconstruction during the middle Paleocene. Small patches of alluvial-fan facies symbols in westernmost Colorado indicate scattered conglomeratic lags.

of the Uinta basin, close to the south flank of the Uinta Mountains. Areas on the northwest flank of the Uinta Mountains where thrusting had been active in latest Cretaceous and Paleocene time began to subside and accumulate sediment. Abundant detritus was shed from the south flank of the Uinta Mountains into a narrow zone along the northern part of the Uinta basin. However, clastic influx to the southern part of the Uinta basin was low.

Stanley and Collinson (1979) documented the following environmental differences across the Wasatch Plateau in late Paleocene time. In the more rapidly subsiding western part of the Wasatch Plateau, lacustrine and wetland environments were dominant, and the lower member of the
Flagstaff Limestone formed. Contemporaneously in the eastern, less rapidly subsiding part of the Wasatch Plateau near the west flank of the San Rafael uplift, floodplains were dominant, and the upper part of the North Horn Formation formed. Wells (1983) also provided a detailed description of the rock types and the inferred depositional environments for the entire Flagstaff Limestone in the Wasatch Plateau area.

Palynomorphs recovered from the basal part of the Claron Formation southwest of the map area indicate a late Paleocene age (P.M. Goldstrand, written commun., 1990). Therefore, this unit is shown forming in the southwestern part of the map area at this time. 


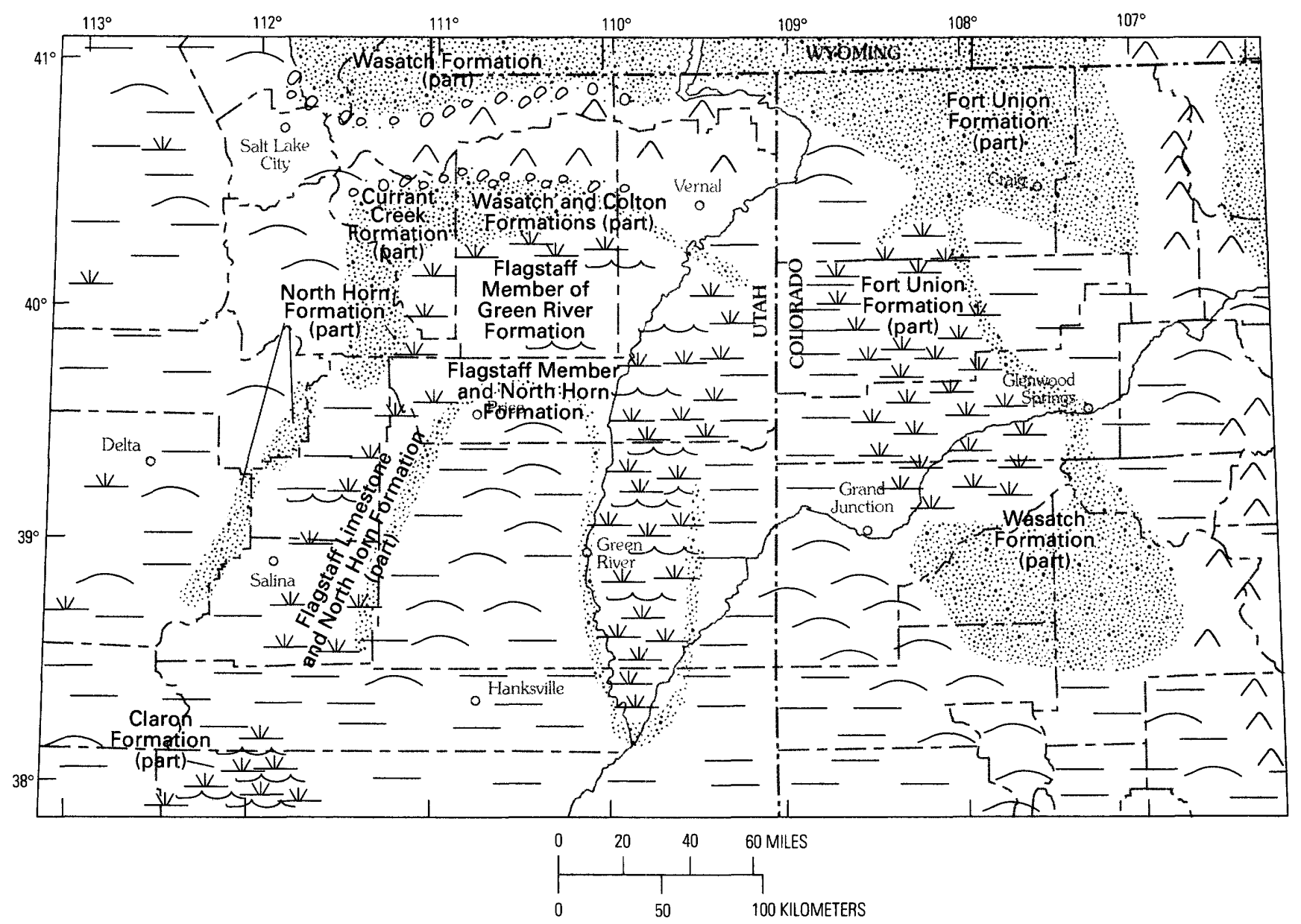

EXPLANATION

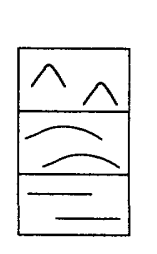

Nondepositional areas

High to moderate relief

Moderate to low relief

Low relief to nonsubsiding

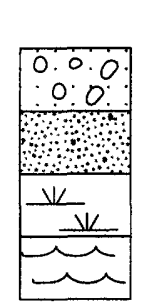

Depositional areas

Alluvial fan

Alluvial plain

Wetlands

Lacustrine

Figure 19. Paleogeographic reconstruction during the early late Paleocene. Flagstaff Member is a member of the Green River Formation.

Wetland and lacustrine environments also expanded and covered much of the Piceance basin during the late Paleocene. The resulting deposits overlie middle to possibly late Paleocene fluvial deposits in the eastern and central areas of the basin and, in the western part of the basin, directly overlie older Paleocene conglomeratic lag deposits, which formed on the Cretaceous-Tertiary unconformity. These upper Paleocene wetland and lacustrine deposits pinch out by depositional onlap on the Cretaceous-Tertiary unconformity a few miles east of the crest of the Douglas Creek arch. This depositional pattern indicates that wetland and lacustrine systems in the Uinta and Piceance basins were not continuous. Upper Paleocene deposits in the
Piceance basin generally contain fewer fossiliferous limestones and more gray shale, carbonaceous shale, and thin coal beds than those in the Uinta basin, which indicates differences in water chemistry, hydrology, and abundance of clastic material in these basins.

In late late Paleocene time, a major influx of feldspathic-rich clastic material into the southern part of the Uinta basin began. Alluvial environments, characterized by sediment derived from the south and southeast, displaced the lacustrine and wetland environments to the north. The lower part of the Colton Formation formed in this alluvial setting. In the Piceance basin, alluvial environments, containing sediment derived from the southwest, southeast, 

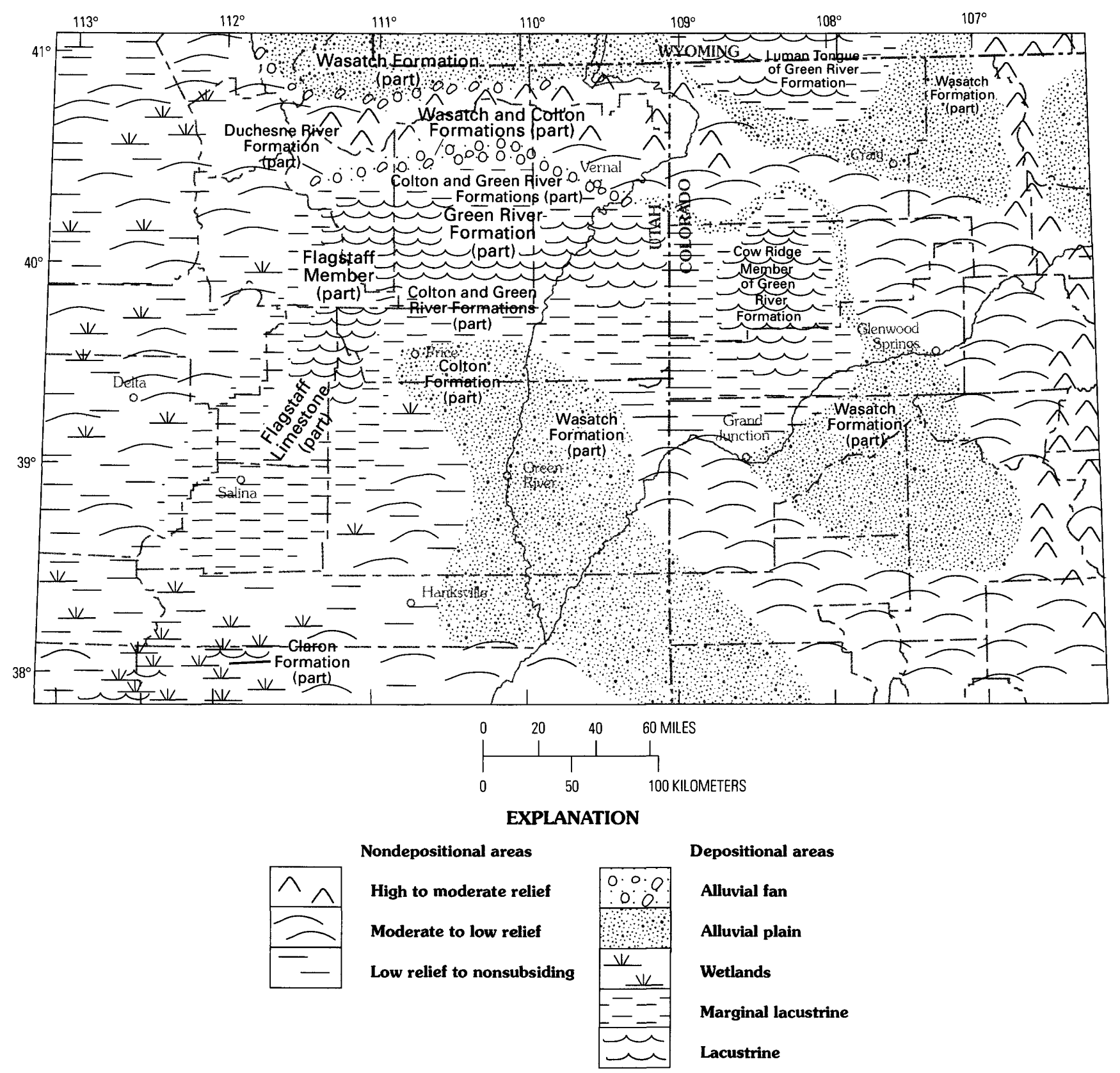

Depositional areas

Alluvial fan

Alluvial plain

Wetlands

Marginal lacustrine

Lacustrine

Figure 20. Paleogeographic reconstruction during the early Eocene. Use of Duchesne River Formation in northwestern part of Uinta basin from Bryant and others (1989a).

and possibly north and northeast, displaced the wetland and lacustrine environments into the north-central part of the basin.

\section{Early Eocene}

The major clastic influx into both the Uinta and Piceance basins that began in late late Paleocene time continued into earliest Eocene time. Subsequently, but still in early Eocene time, the lake systems expanded not only in the Uinta and Piceance basins, but also in the area covered by both the Green River and Sand Wash basins in Wyoming and northwest Colorado north of the Uinta Mountains (fig. 20). A single, large lake that had well-defined open- and marginal-lacustrine zones occupied each of these basins, in contrast to the preceding mixed lacustrine and wetland systems.

A somewhat complicated nomenclature has evolved for these large lakes. Stokes (1986) used the name Green River Lakes to collectively refer to all the large Tertiary lakes that existed in this area of Wyoming, Colorado, and 
Utah. Lake Gosiute refers to the lake that occupied the Green River and Sand Wash basins. Lake Uinta was first applied to a single large lake that extended across both the Uinta and Piceance basins (Bradley, 1931). However, this single large lake existed only briefly, because during most of the early Eocene the low relief area of the Douglas Creek arch separated the lake within the Uinta basin from that in Piceance basin, and during most of the late Eocene a lake existed only in the Uinta basin. Based on the original application of the name Lake Uinta, Johnson (1985) questioned whether anything but the single lake covering both basins should be referred to as Lake Uinta. In our discussion, rather than apply different names to the lakes that occupied the Uinta and Piceance basins before they became connected and when the lake only occupied the Uinta basin in the late Eocene, we use Lake Uinta to refer to the Eocene lakes that occupied the Uinta and Piceance basins.

The early Eocene lake in the Uinta basin has frequently been referred to as Lake Flagstaff. (See Spieker, 1946; Stanley and Collinson, 1979.) However, the early Eocene deposits that constitute the upper part of the Flagstaff Limestone on the Wasatch Plateau (Spieker, 1946; LaRocque, 1960; Stanley and Collinson, 1979; Witkind and others, 1987) formed in a southwest extension of the large Lake Uinta in the Uinta basin (Bradley, 1930; Cashion, 1972; Ryder and others, 1976; Fouch, 1976; Picard, 1985). Therefore, referring to the early Eocene lake system in the Wasatch Plateau and more western areas as the Flagstaff arm of Lake Uinta is more appropriate. During this phase of lake expansion, the previously isolated depositional basins on the allochthon and in the Wasatch Plateau area were united. Beds temporally and lithologically similar to the upper part of the Flagstaff Limestone extend north of the Wasatch Plateau along the east flank of the Wasatch Range on the west side of the Uinta basin. Fouch (1976) assigned these beds to the Flagstaff Member of the Green River Formation because they are also continuous with strata in the Green River Formation along the Uinta basin axis of deposition south of the Uinta Mountains.

The Flagstaff arm may have extended south of the Wasatch Plateau into southwestern Utah and joined what Stokes (1986) called Lake Claron. Mullet (1989) interpreted the Tertiary Claron Formation to have formed in a slowly subsiding area within shallow, localized lake and floodplain environments; long periods of subaerial exposure over extensive areas were common. The age of this formation is not well documented because of the rarity and poor preservation of fossils and the lack of radiometrically datable tuff beds. It is possible that the shallow lakes, wetlands, and floodplains of the Claron depositional system were separated from the Flagstaff arm of Lake Uinta by a nonsubsiding area presently covered by Tertiary volcanic rocks.
In Utah, the most rapid subsidence and thickest accumulation of sediments occurred south of the Uinta Mountains along the northern axis of the rapidly subsiding Uinta basin. In this area, alluvial fans, composed of thick gravel and coarse sand sequences, were shed south from the mountain front toward the edge of Lake Uinta. These deposits form part of the Colton Formation in the northwest and north-central parts of the Uinta basin and indicate high relief in the Uinta Mountains. The conglomeratic alluvialfan beds may have extended to the northeastern basin margin, but drill holes have not yet penetrated them in this part of the basin. These alluvial deposits grade basinward in the marginal- and open-lacustrine deposits of the Green River Formation.

In the western part of the map area, coarse-grained sandstones and conglomerates associated with lake beds are only locally preserved. Areas that were previously highlands in the Sevier thrust belt of central Utah were probably low relief areas interspersed with local wetlands during the early Eocene.

During the early Eocene in Utah, Lake Uinta and the Flagstaff arm contained alkaline, but relatively fresh water that was low in dissolved chloride. Gypsum precipitated to form beds in the open-lacustrine part of the Flagstaff arm (Stanley and Collinson, 1979), and gypsum formed in shallow-lake and pond settings near the margin of the main body of Lake Uinta in the Uinta basin (Ryder and others, 1976; Fouch and Cashion, 1979; Fouch, 1981). Subsequently, the lake water became more saline, and by the end of the early Eocene, waters in the central part of the lake were relatively high in dissolved chlorides, and calciumsulfate precipitates were rare.

The Piceance basin experienced a widespread expansion of the lake system in the early Eocene simultaneous with the expansion in the Uinta basin. Although a mixed lacustrine and wetland system evolved into single large lakes in each basin, the lakes were separate, and the sediments deposited in and adjacent to the lakes in each basin are characterized by notable differences. The center of most rapid subsidence and thickest accumulation of sediment in the Piceance basin is on the east side of the basin adjacent to the White River uplift. Coarse sediments shed from highlands on this uplift form a narrow zone of alluvial (Wasatch Formation) and mixed alluvial and marginallacustrine deposits along the east and north edge of the basin. These sediments are generally not as coarse as those shed from the south flank of the Uinta Mountains, suggesting considerably lower relief on the White River uplift than on the Uinta uplift.

In the Piceance basin, the marginal-lacustrine deposits are characterized by mollusk- and ostracode-rich sandstone and limestone, gray shale, carbonaceous shale, and less commonly, thin coal beds. The deeper water, open-lacustrine deposits are characterized by widespread, 

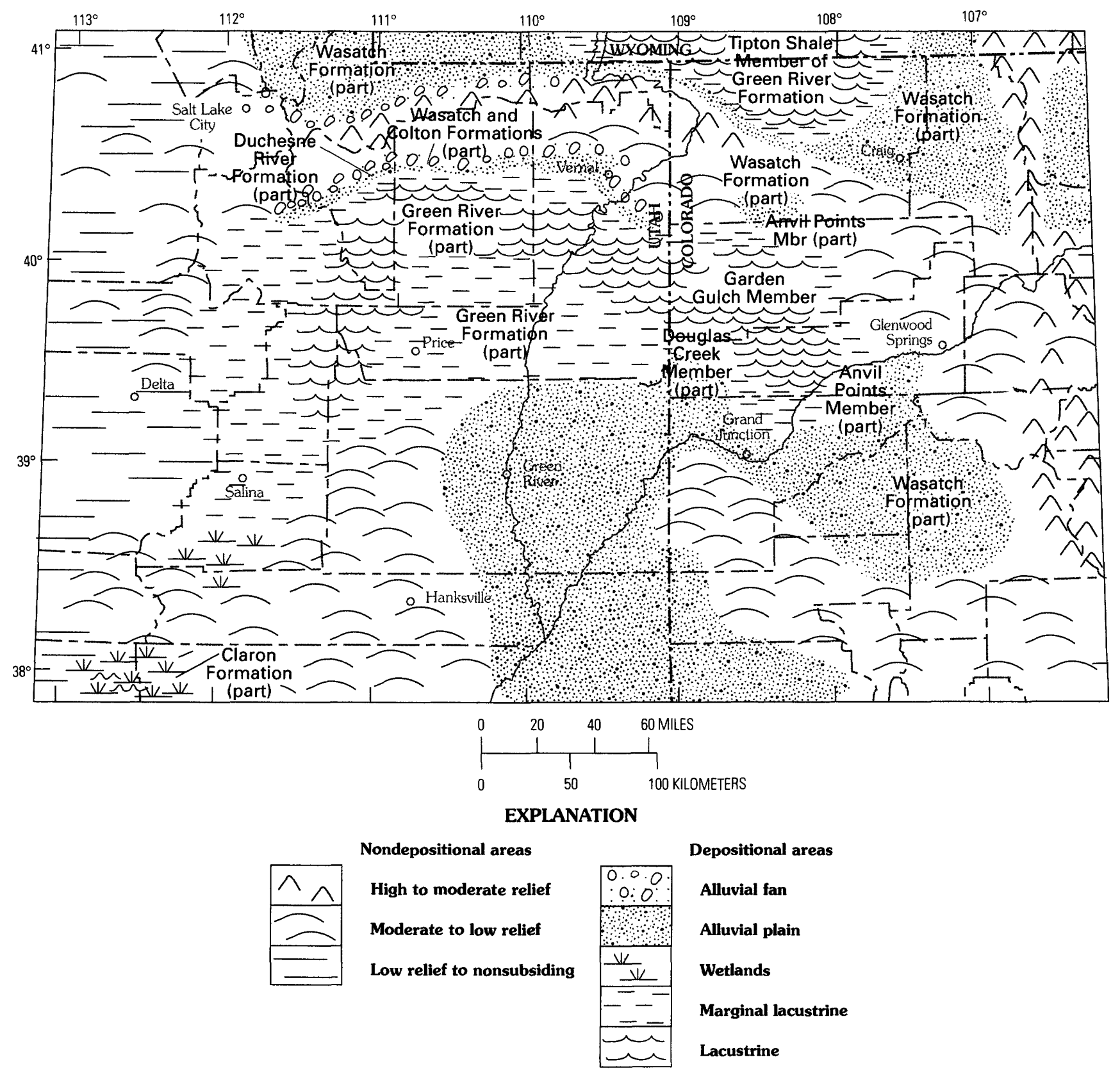

Figure 21. Paleogeographic reconstruction during the middle Eocene (time 1). Use of Duchesne River Formation in northwestern part of Uinta basin from Bryant and others (1989a).

moderately rich, clay-rich oil-shale beds. The lowermost Green River Formation rocks formed in the Piceance basin at this time were originally included in the lower part of the Douglas Creek Member of the Green River Formation by Bradley (1931), but Johnson (1984) renamed them the Cow Ridge Member of the Green River Formation.

The combination of abundant fresh-water mollusks and a lack of evaporite minerals in the marginal-lacustrine deposits of the Cow Ridge Member distinguishes these rocks from the younger, generally mollusk poor Lake Uinta deposits in the Piceance basin. The fossil assemblage and mineralogy also indicate that the salinity of the lake waters during this early Eocene lake phase was low but increased gradually through time.

\section{Middle Eocene}

Near the end of the early Eocene, the lakes in both the Uinta and Piceance basins expanded farther, crossed the Douglas Creek arch, and, during the middle Eocene, united to form the largest of the Paleogene internally drained hydrologic basins (fig. 21). Johnson (1985) referred to the initiation of this expansion in the Piceance as the Long Point 
transgression, based on the widespread occurrence of a mollusk-rich marker bed he named the Long Point Bed of the Douglas Creek Member of the Green River Formation. Although Lake Uinta became one large lake, it had two distinct lacustrine depocenters: one in the Uinta basin slightly south of the axis of maximum subsidence near the south flank of the Uinta Mountains, and one in the Piceance basin slightly west of the area of maximum subsidence along the west flank of the White River uplift.

Abundant sediment continued to be shed from the Uinta Mountains. Analysis of drill-hole lithologic logs of middle Eocene strata indicate that alluvial fans formed near some of the Uinta basin's fault-bounded, high-relief margins and extended from the mountain front into and (or) near Lake Uinta. Sequences as much as $1,000 \mathrm{~m}$ thick of middle and early late(?) Eocene-age lacustrine and fluvial rocks are along the subsidence axis of the Uinta basin. Thick sequences of clastic and chemically precipitated sediments, including the kerogen-rich carbonate mud that became oil shale, formed within the lake in both basins.

The formation of halite $(\mathrm{NaCl})$ and (or) nahcolite $\left(\mathrm{NaHCO}_{3}\right)$ evaporite beds and disseminated dawsonite $\left[\mathrm{NaAl}(\mathrm{OH})_{2} \mathrm{CO}_{3}\right]$ in conjunction with the demise of the mollusk population indicates an increase in lake-water salinity and alkalinity due to absence of an outlet. Initially, precipitation of evaporite minerals occurred only in the lake depocenter in the Piceance basin, suggesting that brines were confined to the Piceance depocenter and that there was probably a net flow of water from the Uinta basin across the shallow lacustrine area around the Douglas Creek arch and into the Piceance (Dyni, 1981; Johnson, 1985). Later, during the filling of the Piceance basin part of Lake Uinta, the area of evaporite deposition shifted westward into the Uinta basin part of Lake Uinta.

During the middle Eocene, Lake Uinta expanded farther (fig. 22). For a relatively short period of time, during deposition of the Mahogany oil-shale bed, the lake reached its maximum extent-when it may have covered the entire Uinta and Piceance sedimentary basins. Its maximum size was probably slightly larger than shown in figure 22 . The extent of the lake along the southern margin of the Uinta basin and in the Wasatch Plateau is unknown because of removal of Tertiary strata by erosion. Isolated exposures of poorly dated lacustrine and fluvial beds in central Utah west of the Wasatch Plateau contain tuffaceous debris. These beds have been mapped as Green River Formation, based on their stratigraphic position and their lithologic similarity to Green River strata in the Uinta basin, but precise correlation of strata between these two areas remains uncertain. Oil shale or tuff of the Mahogany zone has not been identified south and west of the westernmost part of the Uinta basin.

The paleogeographic reconstruction for the western and southwesternmost part of the map area in figure 22 is extremely conjectural. If the Claron depositional system was still active, it probably consisted of interspersed wet- lands and shallow lakes. A gently sloping, nonsubsiding area of alluvial plains and wetlands locally separated by scattered, small uplands of moderate to low relief probably bounded the west side of Lake Uinta and its associated peripheral environments.

\section{Late Eocene}

In middle Eocene time, shortly after deposition of the Mahogany oil-shale bed, a major influx of volcaniclastic sediment originating in western Wyoming came into the northern Piceance basin. These volcaniclastics prograded from north to south across the Piceance basin and filled the northern Piceance part of Lake Uinta. Eventually, these sediments spilled over the Douglas Creek arch and filled Lake Uinta in the eastern part of the Uinta basin before the influx of volcaniclastic debris ended. Accordingly, Lake Uinta's depocenter shifted westward to the western and southwestern part of the Uinta basin. By late Eocene time, Lake Uinta had shrunk to the western and north-central part of the Uinta basin (fig. 23). In the western Uinta basin, a sequence of lacustrine and marginal lacustrine deposits more than $750 \mathrm{~m}$ thick occurs above the Mahogany bed. Locally, more than $300 \mathrm{~m}$ of this sequence is characterized by abundant, bedded evaporite minerals (Dyni and others, 1985), indicating that during the final phase of Lake Uinta the lake still lacked an outlet and the waters had become more saline as the lake retreated westward. Based on isotopic ages of tuff beds in the western Uinta basin, Bryant and others (1989a) determined that lacustrine deposition in this area continued until the latest Eocene, perhaps to 37.6 Ma. The source of the tuffaceous material was probably volcanic centers in west-central Utah, because these tuff beds are younger than the volcanism in Wyoming that supplied the older volcaniclastic sediments, and these tuff beds thicken to the west (J.R. Dyni, written commun., 1990). The southern extent of Lake Uinta on the west side of the Uinta basin is unknown, as rocks of this age have been eroded. The last phase of the lake may have extended southward into the Wasatch Plateau and westward into the easternmost Great Basin.

\section{Latest Eocene and (or) Earliest Oligocene}

During the latest Eocene and (or) earliest Oligocene, the large lakes that dominated most of previous Paleogene time disappeared from this part of the Western United States. Figure 24 illustrates the paleogeography during the latest Eocene and (or) early Oligocene when all that remained of the former Lake Uinta was scattered wetlands. Renewed uplift on the Uinta Mountains during this time resulted in an influx of sediments (the Duchesne River 


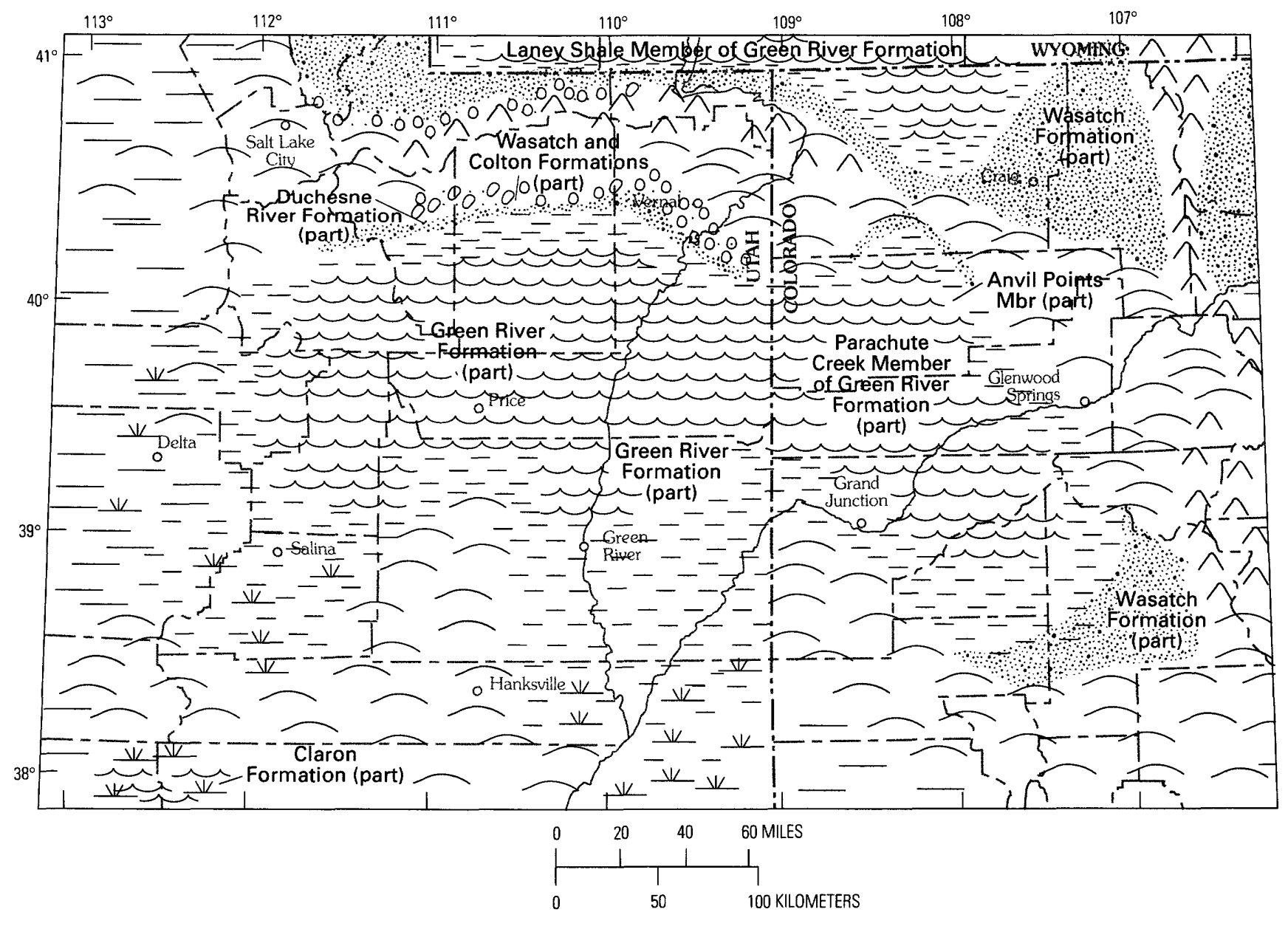

EXPLANATION

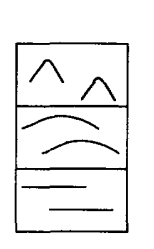

Nondepositional areas

High to moderate relief

Moderate to low relief

Low relief to nonsubsiding

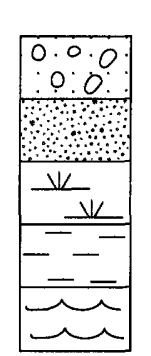

Depositional areas

Alluvial fan

Alluvial plain

Wetlands

Marginal lacustrine

Lacustrine

Figure 22. Paleogeographic reconstruction during the middle Eocene (time 2) during maximum expansion of Lake Uinta as represented by the Mahogany oil-shale bed. Boundaries of the lake at Mahogany time may have been slightly greater than shown here. Anvil Points is a member of the Green River Formation. Use of Duchesne River Formation in northwestern part of Uinta basin from Bryant and others (1989a).

Formation) that filled the northern part of the Uinta basin (Andersen and Picard, 1974; Bryant and Nichols, 1988). A sediment source west of the Gunnison Plateau provided the lithic-rich clastic material in the uppermost lacustrine beds and in the overlying alluvial deposits (the Crazy Hollow Formation) in central Utah (Weiss, 1982). Concurrent with the final uplift of the Uinta Mountains was volcanism in the eastern Great Basin area (Lindsey and others, 1975; Fouch,
1979; Witkind and Marvin, 1989; Bryant and others, $1989 \mathrm{~b})$. Locally extensive deposits of volcanic and volcaniclastic detritus mantled much of the western part of the map area and filled the remaining topographic lows formerly occupied by lakes and wetlands. Parts of the Keetley Volcanics and the mixed volcanic and volcaniclastic Goldens Ranch and Moroni Formations, all of which occur within the map area, formed at this time. 

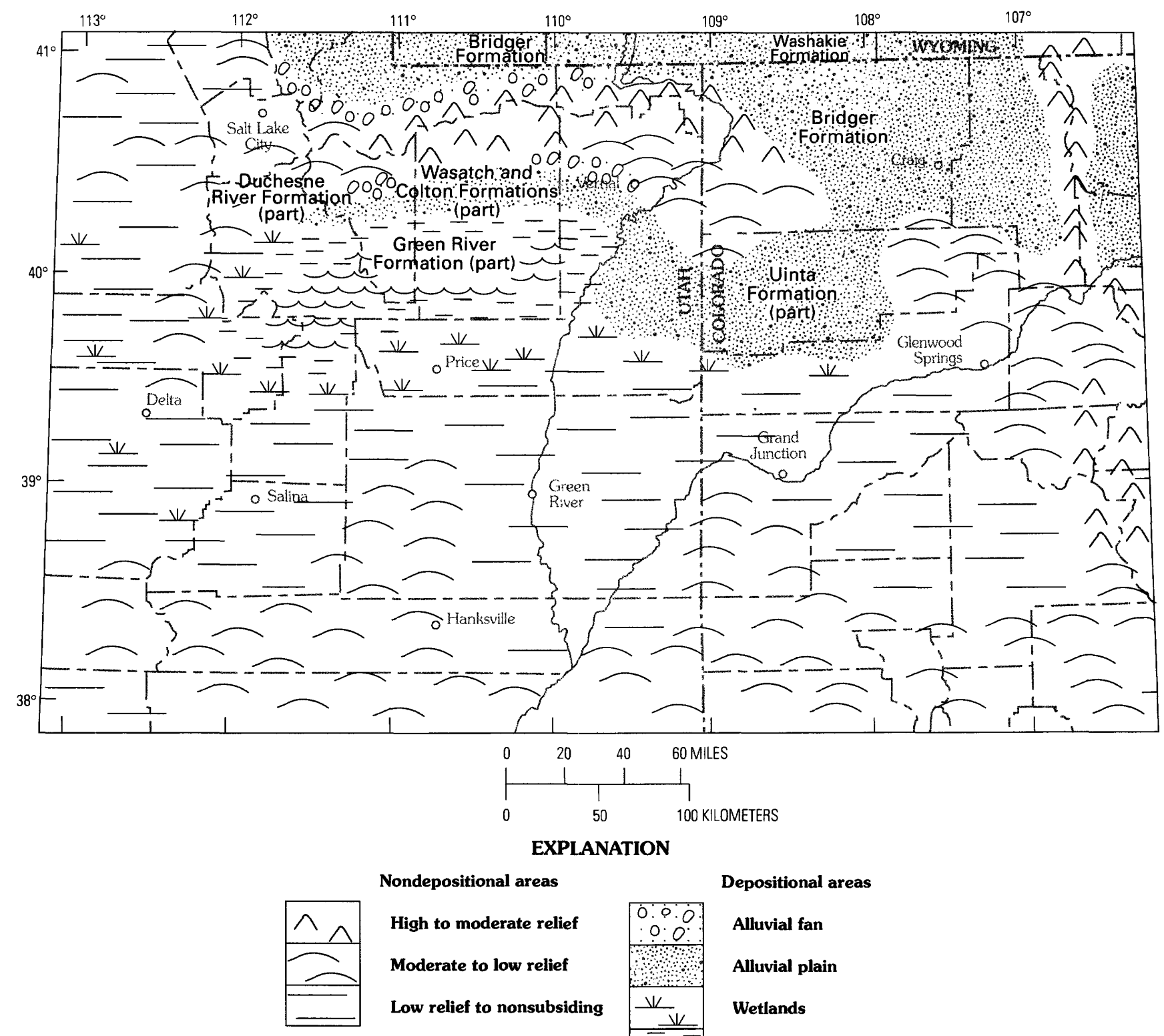

Nondepositional areas

High to moderate relief

Moderate to low relief

Low relief to nonsubsiding

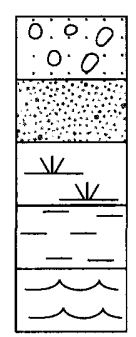

Depositional areas

Alluvial fan

Alluvial plain

Wetlands

Marginal lacustrine

Lacustrine

Figure 23. Paleogeographic reconstruction during the late Eocene. Use of Duchesne River Formation in northwestern part of Uinta basin from Bryant and others (1989a).

\section{SUMMARY}

Figure 25 summarizes the structural and depositional events that occurred in the study area from late early Cretaceous to late Oligocene time. Throughout most of the Late Cretaceous, Sevier-style tectonism, characterized by thin-skinned thrusting, was dominant in the western part of the area and resulted in the formation of a marine foreland basin. In the latest part of the Cretaceous and throughout much of the Paleogene, Laramide-style tectonism, charac- terized by crystalline basement-involved uplifts, was dominant in the area and resulted in the formation of numerous intermontane basins in which large lakes developed. Toward the end of this phase of tectonism, volcanic activity began in the western part of the area. In each case, the final phase of a tectonic event temporally overlaps the initial phase of the succeeding tectonic event.

The paleogeography and resulting lithofacies distributions were influenced by the types of basins that developed during these different tectonic phases. The sea occupied parts of the foreland basin within the study area 


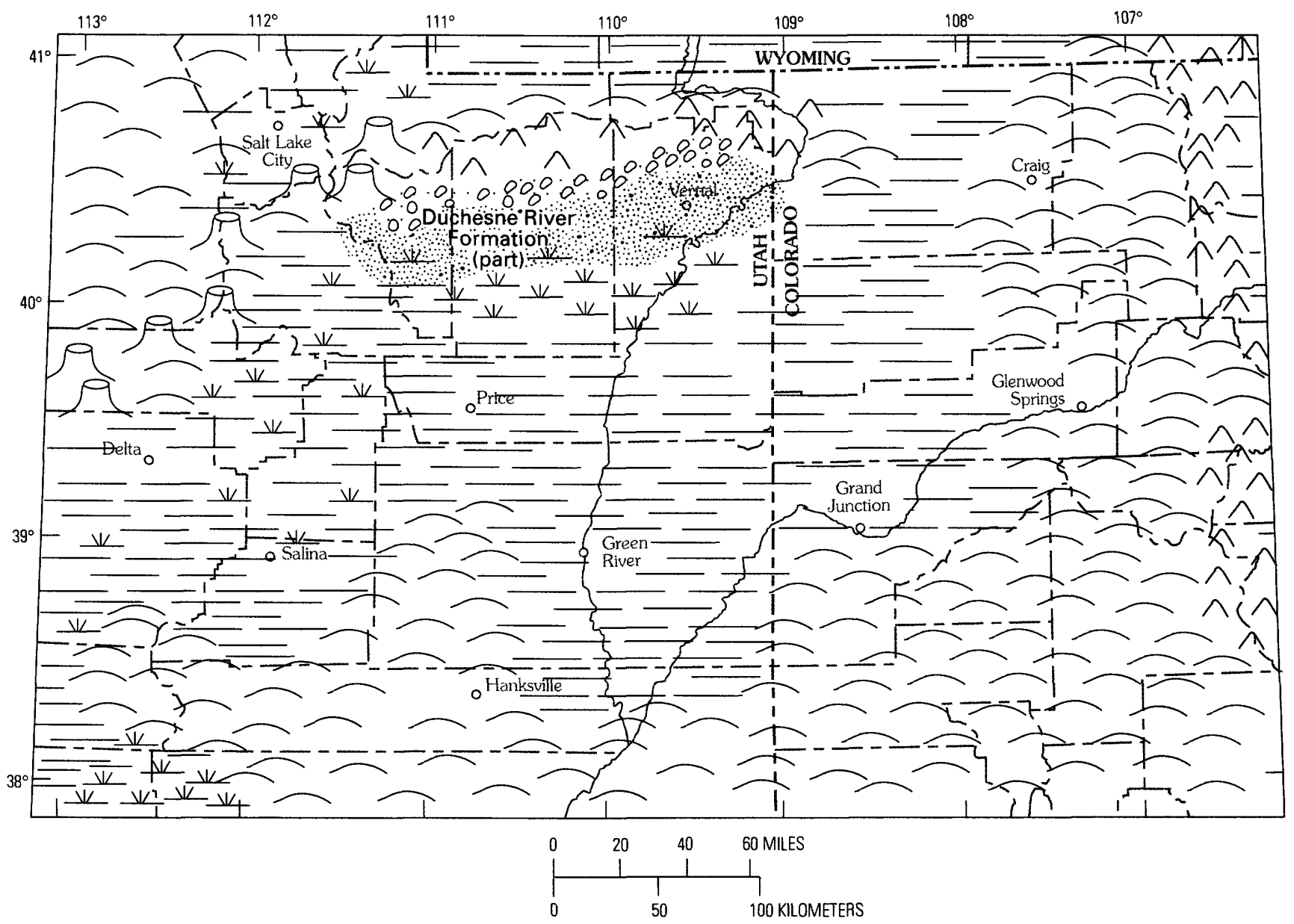

EXPLANATION

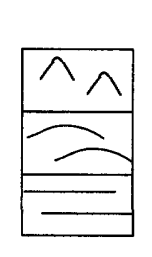

Nondepositional areas

High to moderate relief

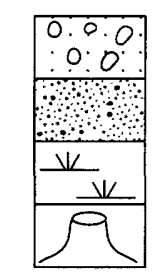

Depositional areas

Moderate to low relief

Low relief to nonsubsiding

Alluvial fan
Alluvial plain
Wetlands
Volcanic area

Figure 24. Paleogeographic reconstruction during the latest Eocene and (or) early Oligocene. Areas surrounding the volcanic centers were locally sites of ash-flow, alluvial, and shallow lacustrine deposition. Exact distribution of these depositional environments is unknown, and this area is shown schematically as consisting of mixed low-relief and wetland areas.

for much of the Late Cretaceous. Nonmarine environments paralleled the thrust belt and graded eastward into marine environments. Repeated transgressions and regressions of the sea resulted in significant changes in shoreline location and produced a depositional sequence of complexly intertonguing nonmarine and marine units. The formation of intermontane basins resulted in internally drained depositional systems in which shallow lakes and wetlands predominated in latest Cretaceous and Paleocene time and large lakes predominated in Eocene time. By middle Eocene time, one lake, Lake Uinta, covered much of the area.
Alluvial environments generally occurred along the basin margins, but their distribution was controlled by the proximity of the surrounding uplifts and the subsidence pattern of the basin. Lacustrine environments generally occurred in the basin interiors, but frequent lake expansions and contractions resulted in large variations in lake size and wide zones of intertonguing alluvial and lacustrine deposits. Saline minerals and oil shale are common within the lacustrine deposits. The lake began to decrease in size toward the end of the middle Eocene and had disappeared by latest Eocene or earliest Oligocene time. 


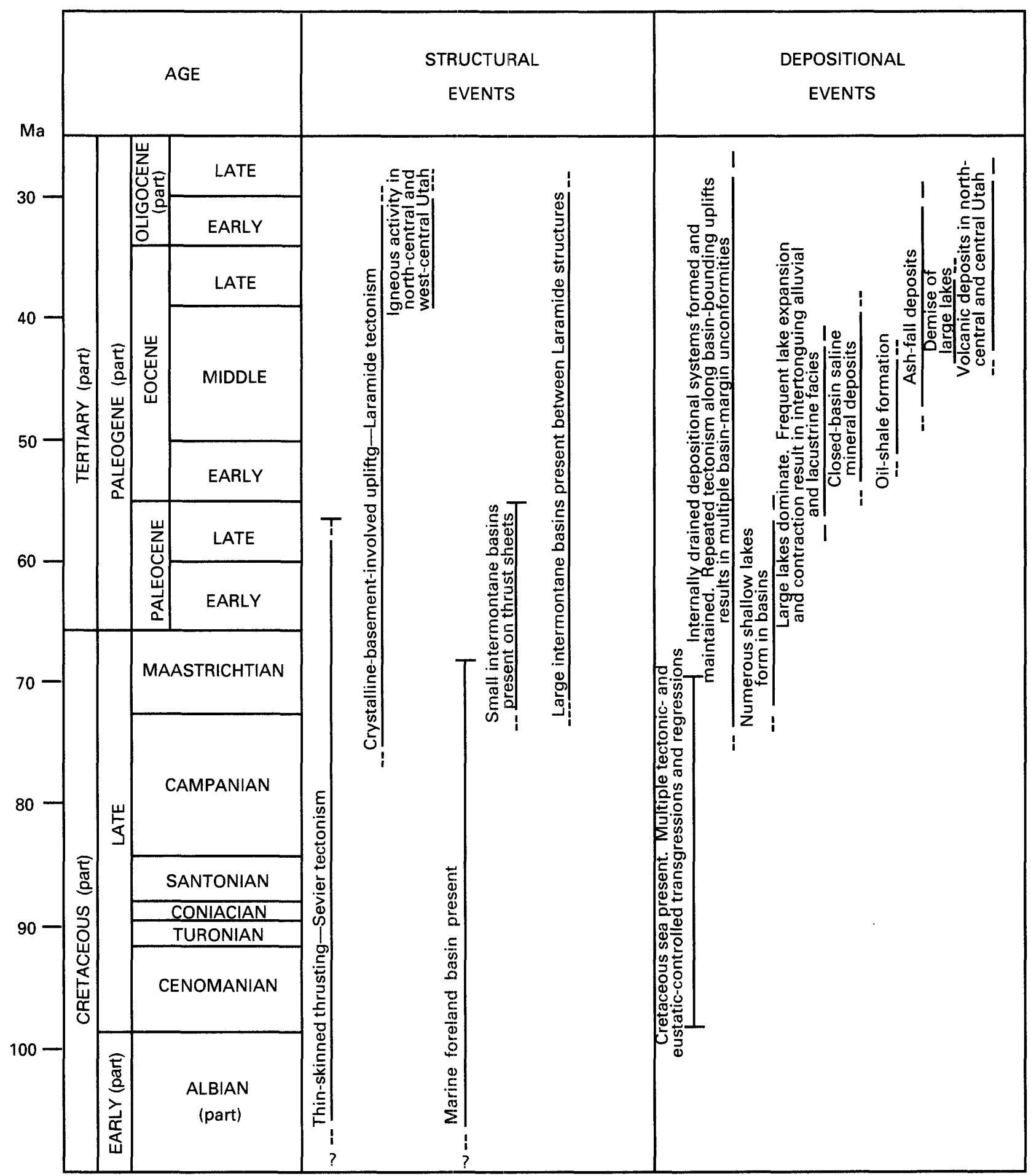

Figure 25. Summary of structural and depositional events in the study area from late Early Cretaceous to late Oligocene time. Time lines are queried where the age of onset of an event is uncertain and are dashed to indicate local variations in the onset and duration of events.

\section{REFERENCES CITED}

Andersen, D.W., and Picard, M.D., 1974, Evolution of synorogenic clastic deposits in the intermontane Uinta basin of Utah, in Dickinson, W.R., ed., Tectonics and sedimentation:
Society of Economic Paleontologists and Mineralogists Special Publication 22, p. 167-189.

Bowers, W.E., 1972, The Canaan Peak, Pine Hollow, and Wasatch Formations in the Table Cliff region, Garfield County, Utah: U.S. Geological Survey Bulletin 1331-B, 39 p. 
Bradley, W.H., 1930, The varves and climate of the Green River epochs: U.S. Geological Survey Professional Paper 158-E, p. 87-110.

1931, Origin and microfossils of the oil shale of the Green River Formation of Colorado and Utah: U.S. Geological Survey Professional Paper 168, 58 p.

Bryant, Bruce, Naeser, C.W., Martin, R.F., and Mehnert, H.H., 1989a, Upper Cretaceous and Paleogene sedimentary rocks and isotopic ages of Paleogene tuffs, Uinta basin, Utah: U.S. Geological Survey Bulletin 1787-J, 22 p.

$1989 \mathrm{~b}$, Ages of late Paleogene and Neogene tuffs and the beginning of rapid regional extension, eastern boundary of the Basin and Range province near Salt Lake City, Utah: U.S. Geological Survey Bulletin 1787-K, 12 p.

Bryant, Bruce, and Nichols, D.J., 1988, Late Mesozoic and Early Tertiary reactivation of an ancient crustal boundary along the Uinta trend and its interaction with the Sevier orogenic belt: Geological Society of America Memoir 171, p. $411-430$.

Cashion, W.B., 1972, Geology and fuel resources of the Green River Formation, southeastern Uinta basin, Utah and Colorado: U.S. Geological Survey Professional Paper 548, $48 \mathrm{p}$.

Clark, F.R., 1928, Economic geology of the Castlegate, Wellington, and Sunnyside quadrangles, Carbon County, Utah: U.S. Geological Survey Bulletin 793, 162 p.

Cobban, W.A., 1976, Ammonite record from the Mancos Shale of the Castle Valley-Price-Woodside area, east-central Utah: Brigham Young University Geology Studies, v. 22, pt. 3, p. 117-128.

Cobban, W.A., and Hook, S.C., 1984, Mid-Cretaceous molluscan biostratigraphy and paleogeography of southwestern part of Western Interior, United States, in Westerman, G.E.G., ed., Jurassic-Cretaceous biochronology and paleogeography of North America: Geological Association of Canada Special Paper 27, p. 257-271.

Cobban, W.A., and Kennedy, W.J., 1989, The ammonite Metengonoceras Hyatt, 1903, from the Mowry Shale (Cretaceous) of Montana and Wyoming: U.S Geological Survey Bulletin 1787-L, $11 \mathrm{p}$.

Cole, R.D., 1987, Cretaceous rocks of the Dinosaur Triangle, in Averett, W.R., ed., Dinosaur Triangle Paleontological Field Trip: Grand Junction, Colo., Grand Junction Geological Society, p. 21-35.

Collins, B.A., 1976, Coal deposits of the Carbondale, Grand Hogback, and southern Danforth Hills coal fields, eastern Piceance basin, Colorado: Colorado School of Mines Quarterly, v. 71, no. 1, 138 p.

Cullins, H.L., 1968, Geologic map of the Banty Point quadrangle, Rio Blanco County, Colorado: U.S. Geological Survey Geologic Quadrangle Map GQ-703, scale 1:24,000.

Dyni, J.R., 1981, Geology of the nahcolite deposits and associated oil shales of the Green River Formation in the Piceance Creek Basin, Colorado: Boulder, Colo., University of Colorado Ph. D. thesis, 144 p.

Dyni, J.R., Milton, Charles, Jr., and Cashion, W.B., Jr., 1985, The saline facies of the upper part of the Green River Formation near Duchesne, Utah, in Picard, M.D., ed., Geology and energy resources, Uinta basin of Utah: Utah Geological Association Publication 12, p. 51-60.
Eaton, J.G., 1990, Stratigraphic revision of Campanian (Upper Cretaceous) rocks in the Henry Basin, Utah: The Mountain Geologist, v. 27, no. 1, p. 27-38.

Fenneman, N.M., and Gale, G.S., 1906, The Yampa coal field, Routt County, Colorado: U.S. Geological Survey Bulletin 297, 96 p.

Fisher, D.J., Erdmann, C.E., and Reeside, J.B., Jr., 1960, Cretaceous and Tertiary formations of the Book Cliffs, Carbon, Emery, and Grand Counties, Utah, and Garfield and Mesa Counties, Colorado: U.S. Geological Survey Professional Paper 332, 80 p.

Fouch, T.D., 1976, Revision of the lower part of the Tertiary system in the central and western Uinta basin, Utah: U.S. Geological Survey Bulletin 1405-C, 7 p.

1979, Character and paleogeographic distribution of Upper Cretaceous(?) and Paleogene nonmarine sedimentary rocks in east-central Nevada, in Armentrout, J.M., Cole, M.R., and TerBest, Harry, eds., Cenozoic paleogeography of the Western United States: Pacific Coast Section, Society of Economic Paleontologists and Mineralogists, Pacific Coast Paleogeography Symposium 3, p. 97-111.

1981, Distribution of rock types, lithologic groups, and interpreted depositional environments for some lower Tertiary and Upper Cretaceous rocks from outcrops at Willow Creek-Indian Canyon through the subsurface of Duchesne and Altamont oil field: U.S. Geological Survey Oil and Gas Investigations Map Chart OC-81.

Fouch, T.D., and Cashion, W.B., 1979, Distribution of rock types, lithologic groups, and depositional environments for some lower Tertiary and Upper Cretaceous, and Upper and Middle Jurassic rocks in the subsurface between Altamont oil field and San Arroyo gas field, northcentral to northeastern Uinta basin, Utah: U.S. Geological Survey OpenFile Report 79-365, 2 sheets.

Fouch, T.D., Cashion, W.B., and Ryder, R.T., 1976, Field guide to lacustrine and related nonmarine depositional environments in Tertiary rocks, Uinta basin, Utah, in Epis, R.C., and Weimer, R.J., eds., Studies in Colorado field geology: Colorado School of Mines Professional Contributions 8, p. 358-384.

Fouch, T.D., Hanley, J.H., Forester, R.M., Keighin, C.W., Pitman, J.K., and Nichols, D.J., 1987, Chart showing lithology, mineralogy, and paleontology of the nonmarine North Horn Formation and Flagstaff Member of the Green River Formation, Price Canyon, central Utah-A principal reference section: U.S. Geological Survey Miscellaneous Investigations Series Map I-1797-A.

Fouch, T.D., Lawton, T.F., Nichols, D.J., Cashion, W.B., and Cobban, W.A., 1983, Patterns and timing of synorogenic sedimentation in Upper Cretaceous rocks of central and northeast Utah, in Reynolds, M.W., and Dolly, E.D., eds., Mesozoic paleogeography of the west-central United States: Rocky Mountain Section, Society of Economic Paleontologists and Mineralogists, Rocky Mountain Paleogeography Symposium 2, p. 305-336.

Franczyk, K.J., and Nichols, D.J., 1988, Changing depositional systems reflecting foreland to intermontane basin transition in Campanian to Paleocene time, Book Cliffs and Wasatch Plateau, Utah: Geological Society of America Abstracts with Programs, v. 20, no. 7, p. 219. 
Franczyk, K.J., Pitman, J.K., Cashion, W.B., Dyni, J.R., Fouch, T.D., Johnson, R.C., Chan, M.A., Donnell, J.R., Lawton, T.F., and Remy, R.R., 1989, Evolution of resource-rich foreland and intermontane basins in eastern Utah and western Colorado: Washington, D.C., American Geophysical Union, 28th International Geological Congress Fijeld Trip Guidebook T 324, 53 p.

Franczyk, K.J., Pitman, J.K., and Nichols, D.J., 1990, Sedimentology, mineralogy, palynology, and depositional history of Upper Cretaceous and lower Tertiary rocks along the Utah Book and Roan Cliffs east of the Green River: U.S. Geological Survey Bulletin 1787-N, 27 p.

Gill, J.R., and Cobban, W.A., 1973, Stratigraphy and geologic history of the Montana Group and equivalent rocks, Montana, Wyoming, and North and South Dakota: U.S. Geological Survey Professional Paper 776, 37 p.

Gill, J.R., and Hail, W.J., Jr., 1975, Stratigraphic sections across Upper Cretaceous Mancos Shale-Mesaverde Group boundary, eastern Utah and western Colorado: U.S. Geological Survey Oil and Gas Investigations Chart OC-68.

Goldstrand, P.M., 1989, Provenance and paleogeographic implications of Late Cretaceous-Paleocene fluvial deposits of southwest Utah: Geological Society of America Abstracts with Programs, v. 21, no. 5, p. 85.

Hail, W.J., Jr., 1973, Geologic map of the Smizer Gulch quadrangle, Rio Blanco and Moffat Counties, Colorado: U.S. Geological Survey Geologic Quadrangle Map GQ-1131, scale 1:24,000.

Haq, B.U., Hardenbol, Jan, and Vail, P.R., 1987, Chronology of fluctuating sea level since the Triassic: Science, v. 235, p. 1156-1167.

Hobbs, R.S., 1989, The physical and magnetic polarity stratigraphy of the Upper Cretaceous-lower Tertiary North Horn and Flagstaff Formations, Gunnison Plateau, central Utah: Los Angeles, Calif., University of Southern California M.S. thesis, $162 \mathrm{p}$.

Isby, J.S., and Picard, M.D., 1983, Currant Creek FormationRecord of tectonism in Sevier-Laramide orogenic belt: University of Wyoming Contributions to Geology, p. 91108.

Jacobson, S.R., and Nichols, D.J., 1982, Palynological dating of syntectonic units in the Utah-Wyoming thrust belt--The Evanston Formation, Echo Canyon Conglomerate, and Little Muddy Creek Conglomerate, in Powers, R.B., ed., Geologic studies of the Cordilleran thrust belt, Volume II: Rocky Mountain Association of Geologists, p. 735-750.

Johnson, R.C., 1984, New names for units in the lower part of the Green River Formation Piceance Creek basin, Colorado: U.S. Geological Survey Bulletin 1529-I, 20 p.

1985, Early Cenozoic history of the Uinta and Piceance Creek basins, Utah and Colorado, with special reference to the development of Eocene Lake Uinta, in Flores, R.M., and Kaplan, S.S., eds., Cenozoic paleogeography of the westcentral United States: Rocky Mountain Section, Society of Economic Paleontologists and Mineralogists, p. 247-276.

1989 , Geologic history and hydrocarbon potential of Late Cretaceous-age, low-permeability reservoirs, Piceance basin, Westem Colorado: U.S. Geological Survey Bulletin 1787-E, $51 \mathrm{p}$.
Johnson, R.C., and May, Fred, 1978, Preliminary stratigraphic studies of the upper part of the Mesaverde Group, the Wasatch Formation, and the lower part of the Green River Formation, DeBeque area, Colorado, including environments of deposition and investigation of palynomorph assemblages: U.S. Geological Survey Miscellaneous Field Studies Map MF-1050, 2 sheets.

1980, A study of the Cretaceous-Tertiary unconformity in the Piceance Creek basin, Colorado; the Ohio Creek Formation (Upper Cretaceous) redefined as a member of the underlying Hunter Canyon or Mesaverde Formation: U.S. Geological Survey Bulletin 1482-B, 27 p.

Kellogg, H.E., 1977, Geology and petroleum of the Mancos B formation, Douglas Creek Arch area, Colorado and Utah, in Veal, H.K., ed., Exploration frontiers of the Central and Southern Rockies: Rocky Mountain Association of Geologists Symposium, p. 167-179.

LaRocque, A., 1960, Molluscan fauna of the Flagstaff formation of central Utah: Geological Society of America Memoir 78, $100 \mathrm{p}$.

Lawton, T.F., 1986, Fluvial systems of the Upper Cretaceous Mesaverde Group and Paleocene North Horn Formation, central Utah; a record of transition from thin-skinned to thick-skinned deformation in the foreland region, in Peterson, J.A., ed., Paleotectonics and sedimentation in the Rocky Mountain Region, United States, Part III, Middle Rocky Mountains: American Association of Petroleum Geologists Memoir 41, p. 423-442.

1989, Piggyback-basin deposits in the Sevier thrust belt, central Utah: Geological Society of America Abstracts with Programs, v. 21, no. 5, p. 104-105.

Lee, W.T., 1909, The Grand Mesa coal field, Colorado: U.S. Geological Survey Bulletin 341, pt. II, p. 316-334.

Lindsey, D.A., Naeser, C.W., and Shawe, D.R., 1975, Age of volcanism, intrusion, and mineralization in the Thomas Range, Keg and Desert Mountains, western Utah: U.S. Geological Survey Journal of Research, v. 3, no. 5, p. 597-604.

MacGinitie, H.D., 1969, The Eocene Green River flora of northwestern Colorado and northeastern Utah: University of California Publication of Geological Sciences, v. 83, p. $1-140$.

Merewether, E.A., and Cobban, W.A., 1986, Biostratigraphic units and tectonism in the mid-Cretaceous foreland of Wyoming, Colorado, and adjoining area, in Peterson, J.A., ed., Paleotectonics and sedimentation in the Rocky Mountain region, United States, Part III, Middle Rocky Mountains: American Association of Petroleum Geologists Memoir 41, p. 443-467.

Merewether, E.A., Molenaar, C.M., and Cobban, W.A., 1983, Map and diagrams showing lithofacies and stratigraphic nomenclature for formations of Turonian and Coniacian age in the middle Rocky Mountains, in Merewether, E.A., ed., Mid-Cretaceous Codell Sandstone Member of Carlile Shale, eastern Colorado: Society of Economic Paleontologists and Mineralogists, Rocky Mountain Section Spring Field Trip Guidebook, p. 19-25.

Molenaar, C.M., 1983, Major depositional cycles and regional correlations of Upper Cretaceous rocks, southern Colorado Plateau and adjacent area, in Reynolds, M.W., and 
Dolly, E.D., eds., Mesozoic paleogeography of the west-central United States: Rocky Mountain Section, Society of Economic Paleontologists and Mineralogists, Rocky Mountain Paleogeography Symposium 2, p. 201224.

Molenaar, C.M., and Cobban, W.A., 1991, Middle Cretaceous stratigraphy on the south and east sides of the Uinta basin, northeastern Utah and northwestern Colorado: U.S. Geological Survey Bulletin 1787-T, 34 p.

Mullet, D.J., 1989, Interpreting the early Tertiary Claron Formation of southern Utah: Geological Society of America Abstracts with Programs, v. 21, no. 5, p. 120.

Newman, K.T., 1974, Palynomorph zones in early Tertiary formations of the Piceance Creek and Uinta Basins, Colorado and Utah, in Murray, D.K., ed., Energy resources of the Piceance Creek Basin, Colorado: Rocky Mountain Association of Geologists Guidebook, 25th Field Conference, p. 47-55.

Newman, S.L., 1985, Sedimentary and depositional history of shallow shelf deposits within the Cretaceous Blackhawk Formation and Mancos Shale, east central Utah: Salt Lake City, Utah, University of Utah M.S. thesis, 158 p.

Nichols, D.J., and Bryant, Bruce, 1986, Palynology of the Currant Creek and Mesaverde Formations in the Currant CreekDuchesne River area, Duchesne and Wasatch Counties, Utah: U.S. Geological Survey Open-File Report 86-160, $7 \mathrm{p}$.

Nichols, D.J., Jacobson, S.R., and Tschudy, R.H., 1982, Cretaceous palynomorph biozones for the central and northern Rocky Mountain region of the United States, in Powers, R.B., ed., Geologic studies of the Cordilleran thrust belt: Denver, Colo., Rocky Mountain Association of Geologists, v. 2, p. 721-733.

Nichols, D.J., and Ott, H.L., 1978, Biostratigraphy and evolution of the Momipites-Caryapollenites lineage in the early Tertiary in the Wind River basin, Wyoming: Palynology, v. 2, p. 93-112.

Obradovich, J.D., and Cobban, W.A., 1975, A time-scale for the Late Cretaceous of the Western Interior of North America, in Caldwell, W.G.E., ed., The Cretaceous system in the Western Interior of North America: Geological Association of Canada Special Paper 13, p. 31-54.

Obradovich, J.D., Mutschler, R.E., and Bryant, Bruce, 1969, Potassium-argon ages bearing on the igneous and tectonic history of the Elk Mountains and vicinity, Colorado-A preliminary report: Geological Society of America Bulletin, v. 80 , no. 9 , p. $1749-1756$.

Oetking, P., Feray, D.E., and Renfro, H.B., 1967, Map No. 2Geological highway map of the southern Rocky Mountain region: Tulsa, Okla., American Association of Petroleum Geologists, scale 1:1,800,000.

Peterson, Fred, Ryder, R.T., and Law, B.E., 1980, Stratigraphy, sedimentology, and regional relationships of the Cretaceous System in the Henry Mountains region, Utah, in Picard, M.D., ed., Henry Mountains symposium: Utah Geological Association Publication 8, p. 151-170.

Pfaff, B.J., 1985, Sedimentologic and tectonic evolution of the fluvial facies of the Upper Cretaceous Castlegate Sandstone, Book Cliffs, Utah: Salt Lake City, Utah, University of Utah M.S. thesis, $124 \mathrm{p}$.
Picard, M.D., 1985, Hypothesis of oil shale genesis, Green River Formation, northeast Utah, northwest Colorado, and southwest Wyoming, in Picard, M.D., ed., Geology and energy resources, Uinta basin of Utah: Utah Geological Association Publication 12, p. 193-210.

Renfro, H.B., and Feray, D.E., 1972, Map No. 5-Geological highway map of the northern Rocky Mountain region; Tulsa, Okla., American Association of Petroleum Geologists, scale $1: 1,800,000$.

Russon, M.P., 1987, Geology, depositional environments, and coal resources of the Helper $71 \frac{1}{2}$-minute quadrangle, Carbon County, Utah: Brigham Young University Geology Studies, v. 34 , pt. 1 , p. $131-168$.

Ryder, R.T., Fouch, T.D., and Elison, J.H., 1976, Early Tertiary sedimentation in the western Uinta basin, Utah: Geological Society of America Bulletin, v. 87, p. 496-512.

Smith, Curtis, 1983, Geology, depositional environments, and coal resources of the Mt. Pennell 2 NW quadrangle, Garfield County, Utah: Brigham Young University Geology Studies, v. 30 , pt. 1 , p. $145-169$.

Spieker, E.M., 1946, Late Mesozoic and early Cenozoic history of central Utah: U.S. Geological Survey Professional Paper 205-D, p. 117-161.

Stanley, K.O., and Collinson, J.W., 1979, Depositional history of the Paleocene-lower Eocene Flagstaff Limestone and coeval rocks, central Utah: American Association of Petroleum Geologists Bulletin, v. 63, no. 3, p. 311-323.

Stokes, W.L., 1986, Geology of Utah: Utah Museum of Natural History and the Utah Geological and Mineral Survey, $300 \mathrm{p}$.

Swift, D.L., Huddleston, P.M., Brenner, R.L., and Thompson, P., 1987, Shelf construction in a foreland basin; storm beds, shelf sandbodies, and shelf-slope depositional sequences in the Upper Cretaceous Mesaverde Group, Book Cliffs, Utah: Sedimentology, v. 34, p. 423-458.

Tschudy, R.H., Tschudy, B.D., and Craig, L.C., 1984, Palynological evaluation of Cedar Mountain and Burro Canyon Formations, Colorado Plateau: U.S. Geological Survey Professional Paper 1281, 24 p.

Tweto, Ogden, 1975, Laramide (Late Cretaceous-early Tertiary) orogeny in the southern Rocky Mountains: Geological Society of America Memoir 144, p. 1-44.

Van de Graaff, F.R., 1972, Fluvial-deltaic facies of the Castlegate Sandstone (Cretaceous), east-central Utah: Journal of Sedimentary Petrology, v. 42, no. 3, p. 558-571.

Weimer, R.J., and Sonnenberg, S.A., 1983, Codell Sandstone, new exploration play, Denver basin, in Mid-Cretaceous Codell Sandstone Member of Carlile Shale, eastern Colorado: Society of Economic Paleontologists and Mineralogists Rocky Mountain Section, Spring Field Trip Guidebook, p. $26-48$.

Weiss, M.P., 1982, Relation of the Crazy Hollow Formation to the Green River Formation, central Utah, in Nielson, D.L., ed., Overthrust belt of Utah: Utah Geological Association Publication 10, p. 285-289.

Wells, N.A., 1983, Carbonate deposition, physical limnology, and environmentally controlled chert formation in PaleoceneEocene Lake Flagstaff, central Utah: Sedimentary Geology, v. 35 , no. 5 , p. 263-296. 
Witkind, I.J., and Marvin, R.F., 1989, Significance of new potassium-argon ages from the Goldens Ranch and Moroni Formations, Sanpete-Sevier Valley area, central Utah: Geological Society of America Bulletin, v. 101, no. 4, p. 534 548.

Witkind, I.J., Standlee, L.A., and Maley, K.F., 1986, Age and correlation of Cretaceous rocks previously assigned to the Morrison(?) Formation, Sanpete-Sevier Valley area, central Utah: U.S. Geological Survey Bulletin 1584, 9 p.

Witkind, I.J., Weiss, M.P., and Brown, T.L., 1987, Geologic map of the Manti $30^{\prime} \times 60^{\prime}$ quadrangle, Emery, Juab, Sanpete, and
Sevier Counties, Utah: U.S. Geological Survey Miscellaneous Investigations Series Map I-1631, scale 1:100,000.

Wolfe, J.A., and Upchurch, G.R., 1987, North American nonmarine climates and vegetation during the Late Cretaceous: Palaeogeography, Palaeoclimatology, Palaeoecology, v. 61, p. 33-77.

Zapp, A.D., and Cobban, W.A., 1960, Some Late Cretaceous strand lines in northwestern Colorado and northeastern Utah: U.S. Geological Survey Professional Paper 400-B, p. B246-B249. 




\section{SELECTED SERIES OF U.S. GEOLOGICAL SURVEY PUBLICATIONS}

\section{Periodicals}

Earthquakes \& Volcanoes (issued bimonthly).

Preliminary Determination of Epicenters (issued monthly).

\section{Technical Books and Reports}

Professional Papers are mainly comprehensive scientific reports of wide and lasting interest and importance to professional scientists and engineers. Included are reports on the results of resource studies and of topographic, hydrologic, and geologic investigations. They also include collections of related papers addressing different aspects of a single scientific topic.

Bulletins contain significant data and interpretations that are of lasting scientific interest but are generally more limited in scope or geographic coverage than Professional Papers. They include the results of resource studies and of geologic and topographic investigations; as well as collections of short papers related to a specific topic.

Water-Supply Papers are comprehensive reports that present significant interpretive results of hydrologic investigations of wide interest to professional geologists, hydrologists, and engineers. The series covers investigations in all phases of hydrology, including hydrology, availability of water, quality of water, and use of water.

Circulars present administrative information or important scientific information of wide popular interest in a format designed for distribution at no cost to the public. Information is usually of short-term interest.

Water-Resources Investigations Reports are papers of an interpretive nature made available to the public outside the formal USGS publications series. Copies are reproduced on request unlike formal USGS publications, and they are also available for public inspection at depositories indicated in USGS catalogs.

Open-File Reports include unpublished manuscript reports, maps, and other material that are made available for public consultation at depositories. They are a nonpermanent form of publication that maybe cited in other publications as sources of information.

\section{Maps}

Geologic Quadrangle Maps are multicolor geologic maps on topographic bases in 7 1/2- or 15-minute quadrangle formats (scales mainly $1: 24,000$ or $1: 62,500$ ) showing bedrock, surficial, or engineering geology. Maps generally include brief texts; some maps include structure and columnar sections only.

Geophysical Investigations Maps are on topographic or planimetric bases at various scales, they show results of surveys using geophysical techniques, such as gravity, magnetic, seismic, or radioactivity, which reflect subsurface structures that are of economic or geologic significance. Many maps include correlations with the geology.

Miscellaneous Investigations Series Maps are on planimetric or topographic bases of regular and irregular areas at various scales; they present a wide variety of format and subject matter. The series also includes 7 1/2-minute quadrangle photogeologic maps on planimetric bases which show geology as interpreted from aerial photographs. The series also includes maps of Mars and the Moon.
Coal Investigations Maps are geologic maps on topographic or planimetric bases at various scales showing bedrock or surficial geology, stratigraphy, and structural relations in certain coal-resource areas.

Oil and Gas Investigations Charts show stratigraphic information for certain oil and gas fields and other areas having petroleum potential.

Miscellaneous Field Studies Maps are multicolor or black-andwhite maps on topographic or planimetric bases on quadrangle or irregular areas at various scales. Pre-1971 maps show bedrock geology in relation to specific mining or mineral-deposit problems; post-1971 maps are primarily black-and-white maps on various subjects such as environmental studies or wilderness mineral investigations.

Hydrologic Investigations Atlases are multicolored or black-andwhite maps on topographic or planimetric bases presenting a wide range of geohydrologic data of both regular and irregular areas; the principal scale is $1: 24,000$, and regional studies are at $1: 250,000$ scale or smaller.

\section{Catalogs}

Permanent catalogs, as well as some others, giving comprehensive listings of U.S. Geological Survey publications are available under the conditions indicated below from the U.S. Geological Survey, Books and Open-File Reports Sales, Box 25286, Denver, CO 80225. (See latest Price and Availability List.)

"Publications of the Geological Survey, 1879-1961" may be purchased by mail and over the counter in paperback book form and as a set microfiche.

"Publications of the Geological Survey, 1962-1970" may be purchased by mail and over the counter in paperback book form and as a set of microfiche.

"Publications of the U.S. Geological Survey, 1971-1981" may be purchased by mail and over the counter in paperback book form (two volumes, publications listing and index) and as a set of microfiche.

Supplements for 1982, 1983, 1984, 1985, 1986, and for subsequent years since the last permanent catalog may be purchased by mail and over the counter in paperback book form.

State catalogs, "List of U.S. Geological Survey Geologic and Water-Supply Reports and Maps For (State)," may be purchased by mail and over the counter in paperback booklet form only.

"Price and Availability List of U.S. Geological Survey Publications," issued annually, is available free of charge in paperback booklet form only.

Selected copies of a monthly catalog "New Publications of the U.S. Geological Survey" is available free of charge by mail or may be obtained over the counter in paperback booklet form only. Those wishing a free subscription to the monthly catalog "New Publications of the U.S. Geological Survey" should write to the U.S. Geological Survey, $582 \mathrm{Na}$ tional Center, Reston, VA 22092.

Note--Prices of Government publications listed in older catalogs, announcements, and publications may be incorrect. Therefore, the prices charged may differ from the prices in catalogs, announcements, and publications. 


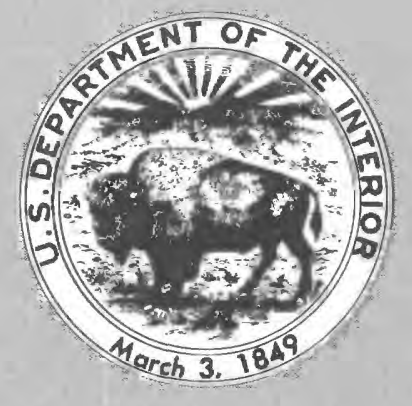

